\title{
Modelling of Surface Water Quality by Catchment Model SWAT
}

\author{
Matjaž Glavan and Marina Pintar \\ University of Ljubljana, Biotechnical Faculty, Agronomy Department, Chair for \\ Agrometeorology, Agricultural Land Management, Economics and Rural Development \\ Slovenia
}

\section{Introduction}

Catchment represents a logical administrative unit of governance as a biological, physical, economic and social system, which is affected by natural (rain, sun) and human influences (industry, agriculture, population). The effective implementation of the river basin management plans are necessary and should include clear and strong objectives and instructions for maintaining the quality of surface water, even if needs of the society are changed in the future (Wagner et al., 2002).

The European Union Water Framework Directive (WFD) (2000/60/EC) set new rules for the catchments water management. The main objectives of the WFD are to improve, protect and prevent a further decreasing of water quality and to achieve good quality status of water bodies in Europe by 2015. The lack of studies and data put doubts on ambitious goals as it is difficult to examine the environmental changes associated with nutrients from biology to ecology (Neal \& Heathwait, 2005). Volk et al. (2009) showed that to reach the WFD target water quality in German study catchments, dramatically unrealistic socio-economic measures would be needed (reduction of cultivated land from $77 \%$ to $46 \%, 13 \%$ of organic farming, increasing pastures from $4 \%$ to $15 \%$ of the forest from $10 \%$ to $21 \%$ and wetlands from $0 \%$ to $9 \%$. Clean Water Act implemented in 1972 in the USA still did not achieve all objectives for drinking and bathing waters even after more than 30 years (Randhir \& Hawes, 2009). Single or uniform integrated catchment management does not meet all the goals in soil and water protection due to usually very heterogeneous catchment characteristics (precipitation, geomorphology, slope, soils, agricultural crops) (Hatch et al., 2001).

Agricultural intensification since 1940 resulted in higher nutrients leaching to water and increased rate of soil erosion. The soil loss with surface migration of soil particles, which exceeds more than $1 \mathrm{t} \mathrm{ha}^{-1}$ year-1 $^{-1}$ is regarded as irreversible within a time span of $50-100$ years (EUSOILS, 2004). In Europe over 54 million $\mathrm{km}^{2}$ of land is suffering similar or a higher rate of loss (Čarman et al., 2007). Erosion can cause significant reduction of the fertile soil depth, a significant loss of nutrients (Ramos \& Martinez-Casasnovas, 2006) and depositions of the fine sediment in rivers, affecting fish spawning and egg development (Lohse, 2008).

Nitrogen $(\mathrm{N})$ is an easily available nutrient and to the most crops is the limiting factor in production. Majority of the loss is associated with leaching in to groundwater and minority 
with surface runoff, depending on the geology and soil type. $\mathrm{N}$ leaching occur during wet periods of the year, after crops are harvested, fertilizers and mineralized crop biomass residues are exposed to leaching (Glavan \& Pintar, 2010), and when N is not actively absorbed by plants and precipitation exceeds evapotranspiration (Rusjan, 2008).

Phosphorus $(\mathrm{P})$ is known as the limiting factor in eutrophication of freshwater ecosystems (Khan \& Ansari, 2005). P is a macronutrient required for the life of all living cells that plants absorb directly in the form of ortho-phosphorus ( $\left.\mathrm{PO}_{4}^{3-}\right)$ (Khan \& Ansari, 2005). Excessive use of $\mathrm{P}$ fertilizers may lead to $\mathrm{P}$ soil saturation, causing $\mathrm{P}$ transport with runoff bound to soil particles or through drainage (Bowatte et al., 2006). Most P in inland waters is contributed by point sources (wastewater treatment plants). Due to advances in wastewater, P stripping has put more emphasis on P from agriculture (Buda et al., 2009).

Computer models in modern integrated catchment management are indispensable for studying the levels of pollutants from diffused sources, as they are capable of merging different spatial and environmental data (Dymond et al., 2003; Kummu et al., 2006). Catchment models can be divided into empirical-statistical (GLEAMS, MONERIS, N-LES), physical (WEPP, SA) and conceptual (distributed or partially distributed - SWAT, NL-CAT, TRK, EveNFlow, NOPOLU, REALTA) (Hejzlar et al., 2009; Kronvang et al., 2009a). Models connected with the Geographic Information System (GIS) has gained new values, as they are more accessible and understandable to different target groups.

Agricultural Research Service (ARS) of the U.S. Department of Agriculture is very active in developing models for agricultural hydrology, erosion and water quality. The Soil and Water Assessment Tool (SWAT) model was developed to assist the water managers in examining the impacts of agricultural activities in catchments (Arnold et al., 1998). The SWAT model is widely used for modelling the hydrology in terms of quantity of water (discharge, soil water, snow and water management), quality of water (land use, production technologies, good agricultural practices, agri-environmental measures) and the effects of climate changes (Gassman et al., 2007; Krysanova \& Arnold, 2008). This model enables the modelling of long-term (more than 25 years) effects of agri-environmental measures (Bracmort et al., 2006). SWAT model has undergone several refinement and upgrades resulting in different model versions (SWAT2000, SWAT2005 and SWAT2009). The overall desire to adapt the model for the local conditions has resulted in many adaptations like G-SWAT, SWIM, E-SWAT, K-SWAT (Gassman et al., 2007).

The European Commission has, for the purposes of ensuring adequate tools, for the end user, that could meet the current European needs for harmonization and transparency in the quantitative assessment of diffused sources of nutrient losses, financially supported EUROHARP project (Kronvang et al., 2009b). This project compared nine different catchment models for simulation of the non-point sources of pollution from agriculture on numerous catchments in Europe. The results of the project ranked SWAT, along with NLCAT and TRK models, in the top three of the best (Schoumans et al., 2009). EUROHARP study showed that the modellers are not yet able to propose only on the best and the most appropriate model for all river basins in Europe, because the quality of the models is based on the input data quality along with quality of the modellers (Kronvang et al., 2009a).

The aim of this chapter is to examine modelling of surface water quality by the catchment model Soil And Water Assessment Tool (SWAT). The capabilities of the model were tested 
through agri-environmental measures and their impacts on quantity and quality of the surface waters.

\section{Materials and methods}

\subsection{Descriptions of the study areas}

The river Reka catchment spreads over $30 \mathrm{~km}^{2}$ and is located in the northwestern part of the country (Goriška Brda) (Fig. 1). Altitude ranges between $75 \mathrm{~m}$ and $789 \mathrm{~m}$ a.s.l. Very steep ridges of numerous hills, which are directed towards the southwest, characterizes the area. The catchment landscape is very agricultural with higher percentages of forest $(56 \%)$ and vineyards (23\%). The river Dragonja catchment area spreads over $100 \mathrm{~km}^{2}$ and is located in the far southwestern part of the country (Istria) (Fig. 1). This is a coastal catchment (Adriatic Sea), with an altitude ranging between 0 and $487 \mathrm{~m}$ a.s.l. The ridges of the hills are designed as a plateau with flat tops and steep slopes. The landscape is largely overgrown with forest $(63 \%)$ and grassland (18\%). Steep slopes allow cultivation only on the terraces.

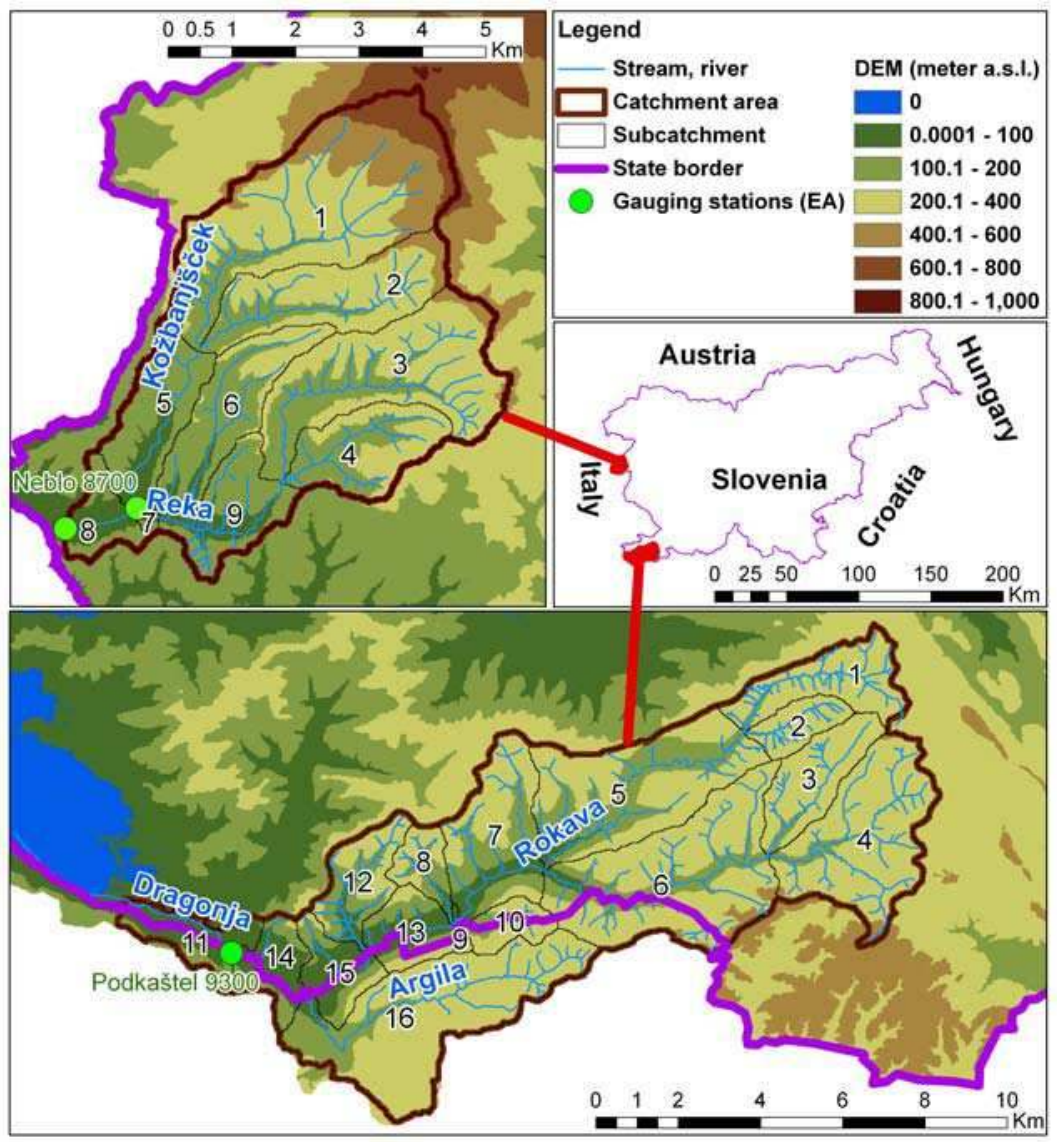

Fig. 1. The river Reka and Dragonja catchment case areas divided in sub-catchments 
Flysch bedrock of the case areas was formed in Eocene as a product of the sea sediments and undersea landslides. Flysch consists of repeated sedimentary layers of sandstones, marl, slate and limestone, which can quickly crumble under the influence of precipitation and temperature changes. Brown eutric soils are shallow and due to silt-loam-clay texture difficult for tillage, with appropriate agro-technical measures (deep ploughing, organic fertilisers) they obtain properties for vine or olive production. In case of inappropriate agricultural activities and land management, we can witness very strong erosion processes.

Both areas are characterized by sub-Mediterranean climate (NE Mediterranean) with southwestern winds and warm and moist air. Average annual temperature at the station Bilje (the Reka catchment), for the period $1991-2009$, was $13.3^{\circ} \mathrm{C}$, with the highest and lowest monthly average in August $\left(22.8^{\circ} \mathrm{C}\right)$ and January $\left(4^{\circ} \mathrm{C}\right)$. Average annual rainfall in the period 1992 - 2008, was 1397 mm, with peaks between September and November (max. in September $184 \mathrm{~mm}$ ). Average annual temperature at the Portorož station (the Dragonja catchment), for the period $1991-2009$, was $14.1^{\circ} \mathrm{C}$, with the highest and lowest monthly average in August $\left(23.4^{\circ} \mathrm{C}\right)$ and January $\left(5.2^{\circ} \mathrm{C}\right)$. Average annual rainfall in the period $1993-2008$, was $930 \mathrm{~mm}$, with peaks between September and November (max. in September $130 \mathrm{~mm}$ ). Both catchments are characterized by fractured aquifer, where water trapped between flysch layers forms surface springs. Alluvial aquifer in the valley bottom overlays impermeable flysch. River network, of the two areas is very extensive. Rivers character is torrential and mediterranean. The river Reka hydrograph recorded (1993-2008) the highest flow rates between October and January with the average flow of $0.98 \mathrm{~m}^{3} \mathrm{~s}^{-1}$ in November and the maximum $24.50 \mathrm{~m}^{3} \mathrm{~s}^{-1}$ in October 1998, and extremely low in the summers. Hydrograph of the river Dragonja recorded (1993-2008) the highest flows between November and April with the average flow of $1.41 \mathrm{~m}^{3} \mathrm{~s}^{-1}$ in January and the maximum $64.70 \mathrm{~m}^{3} \mathrm{~s}^{-1}$ in October 1993, however in the summer the river dries up every year.

The favourable climate and terrain influences at the higher average temperature, better lighting, soil temperatures, minimal risk of frost, wind prevents diseases development. Viticulture is economically most important agricultural sector in both areas, with important share of olive and vegetable productions in the Dragonja area, and fruit production in the Goriška Brda. Terracing is typical for both areas and depends on natural conditions, steepness of the slopes (erosion), geological structure (sliding) and climatic conditions (rainfall). In Goriška Brda (Reka) is 78\% of vineyards terraced while in the Slovenian Istria (Dragonja) about $18 \%$. Vine and olive growing are the sole agricultural sectors, which can withstand the cost of the terraces installation. Terraces in the Dragonja area are characterized by overgrowing, which results in a disordered ownership structure.

The annual average concentration of sediment in the river Reka catchment for one year of research period (July 2008 - June 2009) was $32.6 \mathrm{mg} \mathrm{l}^{-1}$, nitrate $\left(\mathrm{NO}_{3^{-}}\right) 2.7 \mathrm{mg} \mathrm{l}^{-1}$ and $\mathrm{TP}$ concentration of $0.109 \mathrm{mg} \mathrm{l}^{-1}$. In the river Dragonja catchment average annual concentration of sediment in the research period (August 1989 - December 2008), was $29.1 \mathrm{mg} \mathrm{l}^{-1}$ (107 samples), $\mathrm{NO}_{3}^{-} 2.7 \mathrm{mg} \mathrm{l}^{-1}$ (87 samples) and TP concentration of $0.043 \mathrm{mg} \mathrm{l}^{-1}$ (92 samples). In January 2007, the highest sediment concentration measured so far, was $1362 \mathrm{mg} \mathrm{l}^{-1}$. The water quality with exception of sediments does not cause any serious problems in these two study areas. Data shows that sediment concentrations are well in excess of Environment Agency guide level (25 mg l-1). 


\subsection{Database development for the model build}

Before the modelling a field tour to the research areas and review of available data was carried out (Table 1). Since the available data was insufficient for modelling, we perform additional monitoring of surface water quality at the Reka tributary Kožbanjšček hydrological station Neblo, excavation of soil profiles, laboratory measurements and using established model standards (texture, albedo, organic carbon etc) and water-physical soil

\begin{tabular}{|c|c|c|c|}
\hline Data type & Scale & Source & Description/properties \\
\hline Topography & $25 \mathrm{~m} \times 25 \mathrm{~m}$ & $\begin{array}{l}\text { The Surveying and } \\
\text { Mapping Authority of } \\
\text { the Republic of Slovenia }\end{array}$ & $\begin{array}{l}\text { Elevation, overland } \\
\text { and channels slopes, } \\
\text { lengths }\end{array}$ \\
\hline Soils & $\begin{array}{l}\text { Slovenia: } 1: 25,000 \\
\text { Croatia: } 1: 50,000\end{array}$ & $\begin{array}{l}\text { Ministry of Agriculture, } \\
\text { Forestry and Food of the } \\
\text { Republic of Slovenia; } \\
\text { Biotechnical Faculty } \\
\text { (University of Ljubljana); } \\
\text { Faculty of Agriculture } \\
\text { (University of Zagreb) }\end{array}$ & $\begin{array}{l}\text { Spatial soil variability. } \\
\text { Soil types and } \\
\text { properties. }\end{array}$ \\
\hline Land use & $\begin{array}{l}\text { Slovenia: } 1 \mathrm{~m} \times 1 \mathrm{~m} \\
\text { (Graphical Units of } \\
\text { Agricultural Land) } \\
\text { Croatia: } 100 \mathrm{~m} \times 100 \mathrm{~m} \\
\text { (CORINE) }\end{array}$ & $\begin{array}{l}\text { Ministry of Agriculture, } \\
\text { Forestry and Food of the } \\
\text { Republic of Slovenia; } \\
\text { European Environment } \\
\text { Agency }\end{array}$ & $\begin{array}{l}\text { Land cover } \\
\text { classification and } \\
\text { spatial representation }\end{array}$ \\
\hline $\begin{array}{l}\text { Land } \\
\text { management }\end{array}$ & / & $\begin{array}{l}\text { Chamber of Agriculture } \\
\text { and Forestry of Slovenia; } \\
\text { Guidelines for expert } \\
\text { justified fertilization } \\
\text { (Mihelič et al., 2009); } \\
\text { Interviews with farmers }\end{array}$ & $\begin{array}{l}\text { Crop rotations: } \\
\text { planting, management, } \\
\text { harvesting. } \\
\text { Fertiliser application } \\
\text { (rates and time) }\end{array}$ \\
\hline $\begin{array}{l}\text { Weather } \\
\text { stations }\end{array}$ & $\begin{array}{l}\text { Reka: } 2 \text { precipitation, } \\
1 \text { meteo (wind, temp., } \\
\text { rain, humidity, solar) } \\
\text { Dragonja: } \\
3 \text { precipitation, } \\
1 \text { meteo }\end{array}$ & $\begin{array}{l}\text { Environment Agency of } \\
\text { the Republic of Slovenia }\end{array}$ & $\begin{array}{l}\text { Daily precipitation, } \\
\text { temperature (max., } \\
\text { min.), relative } \\
\text { humidity, wind, solar } \\
\text { radiation. }\end{array}$ \\
\hline $\begin{array}{l}\text { Water } \\
\text { abstraction }\end{array}$ & $\begin{array}{l}46 \text { permits } \\
\text { (136 points) }\end{array}$ & $\begin{array}{l}\text { Environment Agency of } \\
\text { the Republic of Slovenia }\end{array}$ & $\begin{array}{l}\text { From surface and } \\
\text { groundwater. }\end{array}$ \\
\hline $\begin{array}{l}\text { Waste water } \\
\text { discharges }\end{array}$ & $\begin{array}{l}\text { Reka: } 2 \text { points } \\
\text { Dragonja: } 1 \text { point }\end{array}$ & $\begin{array}{l}\text { Environment Agency of } \\
\text { the Republic of Slovenia }\end{array}$ & $\begin{array}{l}\text { Registered domestic, } \\
\text { Industrial discharge }\end{array}$ \\
\hline $\begin{array}{l}\text { River } \\
\text { discharge }\end{array}$ & $\begin{array}{l}\text { Reka: } 2 \text { stations } \\
\text { Dragonja } 1 \text { station }\end{array}$ & $\begin{array}{l}\text { Environment Agency of } \\
\text { the Republic of Slovenia }\end{array}$ & $\begin{array}{l}\text { Daily flow data } \\
\left(\mathrm{m}^{3} \text { day }^{-1}\right)\end{array}$ \\
\hline River quality & $\begin{array}{l}\text { Reka: } 0 \text { monitoring } \\
\text { station; Dragonja: } \\
1 \text { monitoring station }\end{array}$ & $\begin{array}{l}\text { Environment Agency of } \\
\text { the Republic of Slovenia }\end{array}$ & $\begin{array}{l}\text { Water quality }\left(\mathrm{mg} \mathrm{l}^{-1}\right) \text { : } \\
\text { sediment, } \mathrm{NO}_{3}^{-} \text {, ortho- } \\
\mathrm{P}, \mathrm{TP}\end{array}$ \\
\hline
\end{tabular}

Table 1. Model input data sources for the Reka and Dragonja catchments 
properties (hydraulic conductivity, water-retention properties etc) (Saxton et al., 1986; Neisch et al., 2005; Pedosphere, 2009). For certain input data an expert assessment was performed, as required measured data was not available. For the purpose of this study we used the SWAT 2005 model and Geographic Information System (GIS) 9.1 software and ArcSWAT interface. Extensions necessary for SWAT functioning in GIS environment are Spatial Analyst, Project Manager and SWAT Watershed Delineator, which enables visualisation of the results.

SWAT is capable of simulating a single catchment or a system of hydrological linked subcatchments. The model of GIS based interface ArcSWAT defines the river network, the main point of outflow from the catchment and the distribution of subcatchments and Hydrological Response Units (HRU). HRUs are basically parts of each subcatchment with a unique combination of land use, soil, slope and land management. This allows the model modelling different ET, erosion, plant growth, surface flow, water balance, etc for each subcatchment or HRU, thus increases accuracy of the simulations (Di Luzio et al., 2005). The river Reka catchment was delineated on 9 subcatchment and 291 HRUs and the river Dragonja catchment on 16 subcatchments and 602 HRUs.

\subsection{Model performance objective functions}

The Pearson coefficient of correlation ( $\left.\mathrm{R}^{2}\right)$ (unit less) for $\mathrm{n}$ time steps (1) describes the portion of total variance in the measured data that can be explained by the model. The range is from 0.0 (poor model) to 1.0 (perfect model). A value of 0 for $\mathrm{R}^{2}$ means that none of the variance in the measured data is replicated by the model, and value 1 means that all of the variance in the measured data is replicated by the model predictions. The fact that only the spread of data is quantified is a major drawback if $\mathrm{R}^{2}$ is considered alone. A model which systematically over or under predicts all the time will still result in good values close to 1.0 even if all predictions were wrong.

$$
R^{2}=\left(\frac{\sum_{i=1}^{n}\left(\text { simulated }_{i}-\text { simulated }_{\text {average }}\right)\left(\text { measured }_{i}-\text { measured }_{\text {average }}\right)}{\sqrt{\sum_{i=1}^{n}\left(\text { simulated }_{i}-\text { simulated }_{\text {average }}\right)^{2}} \sqrt{\sum_{i=1}^{n}\left(\text { measured }_{i}-\text { mesured }_{\text {average }}\right)^{2}}}\right)^{2}
$$

The Nash-Sutcliffe simulation efficiency index ( $E_{N S}$ ) (unit less) for $n$ time steps (2) is widely used to evaluate the performance of hydrological model. It measures how well the simulated results predict the measured data. Values for $\mathrm{E}_{\mathrm{NS}}$ range from negative infinity (poor model) to 1.0 (perfect model). A value of 0.0 means, that the model predictions are just as accurate as using the measured data average. A value greater than 0.0 means, that the model is a better predictor of the measured data than the measured data average. The $\mathrm{E}_{\mathrm{NS}}$ index is an improvement over $\mathrm{R}^{2}$ for model evaluation purposes because it is sensitive to differences in the measured and model-estimated means and variance (Nash \& Sutcliffe, 1970). A major disadvantage of Nash-Sutcliffe is the fact that the differences between the measured and simulated values are calculated as squared values and this places emphasis on peak flows. As a result the impact of larger values in a time series is strongly overestimated whereas lower values are neglected. Values should be above zero to indicate minimally acceptable performance. 


$$
E_{N S}=1-\left(\frac{\left.\sum_{i=1}^{n} \text { (measured }_{i}-\text { simulated }_{i}\right)^{2}}{\sum_{i=1}^{n}\left(\text { measured }_{i}-\text { measured }_{\text {average }}\right)^{2}}\right)
$$

Root Mean Square Error - RMSE (3) is determined by calculating the standard deviation of the points from their true position, summing up the measurements, and then taking the square root of the sum. RMSE is used to measure the difference between flow (q) values simulated by a model and actual measured flow (q) values. Smaller values indicate a better model performance. The range is between 0 (optimal) and infinity.

$$
R M S E=\sqrt{\frac{\sum_{i=1}^{n}\left(q_{t}^{\text {simulated }}-q_{t}^{\text {measured }}\right)^{2}}{n}}
$$

Percentage bias - PBIAS (\%) (4) measures the average tendency of the simulated flows (q) to be larger or smaller than their observed counter parts (Moriasi et al., 2007). The optimal value is 0 , and positive values indicate a model bias toward underestimation and vice versa.

$$
\text { PBIAS }=\left(\frac{\sum_{i=1}^{n}\left(q_{t}^{\text {measured }}-q_{t}^{\text {simulated }}\right)}{\sum_{i=1}^{n}\left(q_{t}^{\text {measured }}\right)}\right) \cdot 100 \%
$$

Model calibration criteria can be further based on recommended percentages of error for annual water yields suggested from the Montana Department of Environment Quality (2005) who generalised information related to model calibration criteria (Table 2) based on a number of research papers.

\begin{tabular}{|c|c|}
\hline Errors (Simulated-Measured) & Recommended Criteria \\
\hline Error in total volume & $10 \%$ \\
\hline Error in 50\% of lowest flows & $10 \%$ \\
\hline Error in 10\% of highest flows & $15 \%$ \\
\hline Seasonal volume error (summer) & $30 \%$ \\
\hline Seasonal volume error (autumn) & $30 \%$ \\
\hline Seasonal volume error (winter) & $30 \%$ \\
\hline Seasonal volume error (spring) & $30 \%$ \\
\hline
\end{tabular}

Table 2. Model calibration hydrology criteria by Montana Department of Environment Quality (2005)

For the detection of statistical differences between the two base scenarios and alternative scenarios Student t-test statistics should be used $(\alpha=0.025$, degrees of freedom $(S P=n-1)$ ), for comparing average annual value of two dependent samples at level of significance 0.05 (5). Variable, which has approximately symmetrical frequency distribution with one modus class, is in the interval $\bar{x} \pm$ s expected $2 / 3$ of the variables and in $\bar{x} \pm 2$ s approximately $95 \%$ of the variables and in $\bar{x} \pm 3 \mathrm{~s}$ almost all variables. Confidence interval $\left(l_{1,2}\right)(6)$ for Student distribution for all sample arithmetic means $(\bar{x})$ can be calculated (6).

$$
t=\frac{\bar{x}-\mu}{s / \sqrt{n}}
$$




$$
t=\bar{x} \pm t_{\frac{\alpha}{2}}(n-1) \cdot \frac{s}{\sqrt{n}}
$$

$\bar{x} \quad$ sample arithmetic mean (alternative scenario)

$\mu \quad$ average of the corresponding random variables (base scenario)

$s \quad$ sample standard deviation (alternative scenario)

$n \quad$ number of pairs (alternative scenario)

$t_{\alpha} \quad$ Student distribution

$\overline{2}$

\section{Sensitivity analysis}

If the model in certain areas has not been used, then it is necessary to carry out sensitivity analysis. Sensitivity analysis limits the number of parameters that need optimization to achieve good correlation between simulated and measured data. The method of analysis in the SWAT model called PARASOL is based on the method of Latin Hypercube One-factorat-a-Time (LH-OAT). LH-OAT combines the advantages of global and local sensitivity analysis (van Griensven et al., 2006). This method performs LH sampling of data at first, followed by OAT sampling. The new scheme allows the LH-OAT to unmistakably link the changes in the output data of each model to the modified parameter (van Griensven et al., 2006). For the sensitivity analysis and calibration a special tool called SWAT-CUP is available which includes all important algorithms (GLUE, PSO, MCMC, PARASOL and SUFI2) of which Sequential Uncertainty Method (SUFI2) was shown to be very effective in identifying sensitive parameters (Abbaspour et al., 2007).

Tool within the model can automatically carry out the sensitivity analysis without the measured data or with the measured data. The tool varies values of each model parameter within a range of (MIN, MAX). Parameters can be multiplied by a value (\%), part of the value can be added to the base value, or the parameter value can be replaced by a new value. The final result of the sensitivity analysis are parameters arranged in the ranks, where the parameter with a maximum effect obtains rank 1 , and parameter with a minimum effect obtains rank which corresponds to the number of all analyzed parameters. Parameter that has a global rank 1, is categorized as "very important", rank $2-6$ as "important", rank $7-41$ (i.e. the number of parameters in the analysis - i.e. flow 7 - 26) as "slightly important" and rank 42 (i.e. flow 27) as "not important" because the model is not sensitive to change in parameter (van Griensven et al., 2006).

Sensitivity analysis was performed using the measured data of the river Reka tributary Kožbanjšček (subcatchment 5) and the river Dragonja (subcatchment 14). The analysis was performed for an average daily flow, sediments, TP and $\mathrm{NO}_{3}$. Table 3 represents for each model the first 10 parameters that have the greatest impact on the model when they are changed. The sensitivity analyses demonstrated great importance of the hydrological parameters that are associated with surface and subsurface runoff.

Alpha_Bf factor determines the share between the base and surface flow contribution to the total river flow. $\mathrm{Cn} 2$ curve runoff determines the ratio between the water drained by the surface and subsurface runoff in moist conditions. Ch_K2 describes the effective hydraulic conductivity of the alluvial river bottom (water losing and gaining). Surlag represents the 
surface runoff velocity of the river and Esco describes evaporation from the soil. For the sediment modelling the most important parameters are Spcon and Spexp that affect the movement and separation of the sediment fractions in the channel. Ch_N - Manning coefficient for channel, determines the sediment transport based on the shape of the channel and type of the river bed material. Ch_Cov - Channel cover factor and Ch_Erod - Channel erodibillity factor proved to be important for the Dragonja catchment. Soil erosion is closely related to the surface runoff hydrological processes (Surlag, Cn2). The analysis showed importance of the hydrological parameters that are associated with surface and subsurface runoff (Cn2, Canmx, Sol_Awc), evaporation (Revapmin, Esco, Blai), base flow (Alpha_Bf) and groundwater (Rchrg_Dp, Gwqmn), suggesting numerous routes by which sediment nitrate nitrogen $\left(\mathrm{NO}_{3}-\mathrm{N}\right)$ and TP are transported (Table 3). We noticed that the amount of $\mathrm{N}$ is also influenced by other parameters that are not included in the sensitivity analysis tool like Rate factor for humus mineralization of organic nutrients active $\mathrm{N}$ and P (CMN.bsn), half-life of nitrates and the shallow aquifer (HLIFE_NGW.gw), fraction of algal biomass that is $\mathrm{N}$ (Al1.wwq). TP results are significantly affected by the parameters that control surface runoff (Cn2, Canmx, Usle_P). Usle_P factor adjusts the USLE value for a particular land management. This means that the soil loss from the terraced land is different, from non terraced slopes. Parameters which have a significant impact on $\mathrm{P}$, but not included in the sensitivity analysis tool are: fraction of algal biomass that is $\mathrm{P}$ (Al2.wwq), $\mathrm{P}$ availability index (PSP.bsn), P enrichment ratio for loading with sediment (ERORGP.hru), BC4.swq, benthic sediment source rate for dissolved $P$ in the reach (RS2.swq), organic P settling rate (RS5.swq).

\begin{tabular}{|c|c|c|c|c|c|}
\hline \multirow{2}{*}{$\begin{array}{c}\text { Base } \\
\text { model }\end{array}$} & \multicolumn{4}{|c|}{ Sensitivity Analysis Objective function (SSQR) } & \multirow{2}{*}{ Category } \\
\hline & Flow & Sediment & $\mathrm{NO}_{3}-\mathrm{N}$ & TP & \\
\hline \multirow{6}{*}{ D } & Surlag & Spcon & $\mathrm{Cn} 2$ & Usle_P & Very important \\
\hline & AlphaBf & Ch_N & Revapmin & $\mathrm{Cn} 2$ & \multirow{5}{*}{$\begin{array}{l}\text { Important } \\
\quad(2-6)\end{array}$} \\
\hline & $\mathrm{Cn} 2$ & Surlag & Alpha_Bf & AlphaBf & \\
\hline & Ch_K2 & Spexp & Esco & Surlag & \\
\hline & Esco & $\mathrm{Cn} 2$ & RchrgDp & Ch_K2 & \\
\hline & Ch_N & Alpha_Bf & Sol_Awc & Slope & \\
\hline \multirow{6}{*}{ 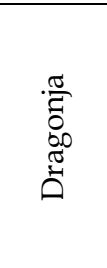 } & $\mathrm{Cn} 2$ & Spcon & Blai & Canmx & Very important \\
\hline & AlphaBf & Ch_Erod & Sol_Awc & AlphaBf & \multirow{5}{*}{$\begin{array}{l}\text { Important } \\
\quad(2-6)\end{array}$} \\
\hline & Ch_K2 & Ch_Cov & $\mathrm{Cn} 2$ & Blai & \\
\hline & RchrgDp & Ch_N & Revapmin & Surlag & \\
\hline & Esco & Spexp & RchrgDp & Cn2 & \\
\hline & Surlag & Surlag & Sol_Z & Sol_Z & \\
\hline
\end{tabular}

Table 3. SWAT parameters ranked by the sensitivity analysis for the Reka subcatchment 5 and Dragonja subcatchment 14 (1998 - 2005)

\section{Calibration and validation}

During the model calibration parameters are varied within an acceptable range, until a satisfactory correlation is achieved between measured and simulated data. Usually, the parameters values are changed uniformly on the catchment level. However, certain 
parameters (Sol_Awc, Cn2, Canmx) are exceptions, because of the spatial heterogeneity. Firstly manual calibration, parameter by parameter, should be carried out with gradual adjustments of the parameter values until a satisfactory output results ( $E_{N S}$ and $R^{2>} 0.5$ ) (Moriasi et al., 2007, Henriksen et al., 2003). This procedure may be time consuming for inexperienced modellers. In the process of autocalibration only the most sensitive parameters are listed that showed the greatest effect on the model outputs. For each of the parameter a limit range ( $\max , \min )$ has to be assigned.

Validation is performed with parameter values from the calibrated model (Table 4) and with the measured data from another time period. Due to the data scarcity, the model was validated only for the hydrological part (flow). The river Reka water quality data covers only one year of daily observations, which was only enough for the calibration. For the river Dragonja a 14 years long data series of water quality was available, but the data was scarce in the number of observations (for sediment, $\mathrm{NO}_{3}$ - and TP only 92, 73, 75, 78 measurements). It should be pointed out that samples taken during monitoring represents only the current condition of the river in a certain part of the day (concentration in $\mathrm{mg} \mathrm{l}^{-1}$ ), while the simulated value is a total daily transported load $\left(\mathrm{kg} \mathrm{day}^{-1}\right)$ in a river.

Calibration of the daily flow for the rivers Reka and Dragonja catchments was performed for the period from 1998 to 2005. According to the availability of data we selected different periods for the daily flow validation of the Reka (1993-1997, 2006-2008) and Dragonja (1994-1996, 2006-2008). Due to the lack of data, on sediment, $\mathrm{NO}_{3}{ }^{-}$and $\mathrm{TP}$, we performed only the calibration for Kožbanjšček (1. 7. 2008 - 30. 6. 2009) and Dragonja (1994-2008).

\begin{tabular}{|c|c|c|c|c|c|}
\hline \multicolumn{2}{|c|}{ Parameter } & \multirow{2}{*}{ Default } & \multirow{2}{*}{ Range } & \multicolumn{2}{c|}{ Calibrated values } \\
\cline { 5 - 6 } & & & Reka & Dragonja \\
\hline 1 & Alpha_Bf & 0.048 & $0-1$ & 0.30058 & 0.45923 \\
\hline 2 & Canmx ${ }^{1}$ & 0 & $0-20$ & $8,4,2$ & $8,4,2$ \\
\hline 3 & Ch_K2 & D & $0-150$ & 7.0653 & 3.7212 \\
\hline 4 & Ch_N & D & $0-1$ & 0.038981 & 0.04363 \\
\hline 5 & Cn2 & D & $-25 /+25 \%$ & $-8,-152$ & +14 \\
\hline 6 & Esco & 0.95 & $0-1$ & 0.8 & 0.75 \\
\hline 7 & Gw_Delay & 31 & $0-160$ & 131.1 & 60.684 \\
\hline 8 & Gw_Revap & 0.02 & $0-0.2$ & 0.19876 & 0.069222 \\
\hline 9 & Gwqmn & 0 & $0-100$ & 100 & 0.79193 \\
\hline 10 & Sol_Awc & D & $+50 \%$ & no change & no change \\
\hline 11 & Surlag & 4 & $0.01-4$ & 0.28814 & 0.13984 \\
\hline ENS & & & & 0.61 & 0.57 \\
\hline
\end{tabular}

Legend: ${ }^{1}$ - forest, permanent crops, grassland, arable; ${ }^{2}$ - subcatchment 1-2-5, subcatchment 3-4-6-7-8-9; D - default value - depends on soil type, land use and modeller set up

Table 4. Hydrological parameters, ranges and final values selected for the calibration of models (SWAT) for the rivers Reka and Dragonja catchments

\subsection{Hydrology calibration and validation}

Objective functions show that the simulated total flows are within the acceptable range (Table 5, Fig. 2). Correlation coefficient (R2) for a daily flow is influenced by low flows. 
Official measurements of a flow showed that on certain days the flow was not present or it was negligible. Model does not neglect extremely low flows, as is evident from the cumulative distribution of the flow (Fig. 2). Errors in flow measurements, in the worst case may be upto $42 \%$ and in best case upto $3 \%$ of the total flow (Harmel et al., 2006).

The $E_{N S}$ values for total flow fall into the category of satisfactory results (Moriasi et al., 2007, Henriksen et al., 2003), $\mathrm{R}^{2}$ values fall into the category of good results, RMSE into the category of very good results (Henriksen et al., 2003) and PBIAS into the category of very good and good results (Moriasi et al., 2007). The reasons for lower results of the objective functions in the validation lie in the representation of the soil, rainfall and in the river flow data uncertainty.

\begin{tabular}{|c|c|c|c|c|c|c|c|c|}
\hline \multirow[b]{3}{*}{$\begin{array}{l}\text { Objective } \\
\text { function }\end{array}$} & \multicolumn{4}{|l|}{ Reka } & \multicolumn{4}{|c|}{ Dragonja } \\
\hline & \multicolumn{2}{|c|}{ Calibration } & \multicolumn{2}{|c|}{$\begin{array}{l}\text { Validation } \\
\text { (Total Flow) }\end{array}$} & \multicolumn{2}{|c|}{ Calibration } & \multicolumn{2}{|c|}{$\begin{array}{l}\text { Validation } \\
\text { (Total Flow) }\end{array}$} \\
\hline & $\begin{array}{l}\text { Base } \\
\text { Flow }\end{array}$ & $\begin{array}{l}\text { Total } \\
\text { Flow }\end{array}$ & $\begin{array}{l}1993 \text { - } \\
1997\end{array}$ & $\begin{array}{l}2006- \\
2008\end{array}$ & $\begin{array}{l}\text { Base } \\
\text { Flow }\end{array}$ & $\begin{array}{l}\text { Total } \\
\text { Flow }\end{array}$ & $\begin{array}{l}1994- \\
1996\end{array}$ & $2006-$ \\
\hline $\mathrm{E}_{\mathrm{NS}}$ & 0.61 & 0.61 & 0.39 & 0.69 & 0.55 & 0.57 & 0.45 & 0.42 \\
\hline $\mathbf{R}^{2}$ & 0.72 & 0.64 & 0.57 & 0.70 & 0.66 & 0.59 & 0.49 & 0.49 \\
\hline RMSE & 0.13 & 0.82 & 1.21 & 0.74 & 0.35 & 1.06 & 1.98 & 1.50 \\
\hline PBIAS & -12.79 & 7.04 & -14.19 & 19.40 & 1.49 & 4.69 & 23.15 & -3.31 \\
\hline
\end{tabular}

Table 5. Daily time step river flow performance statistics for the rivers Dragonja and Reka for the calibration (2001-2005) and validation periods
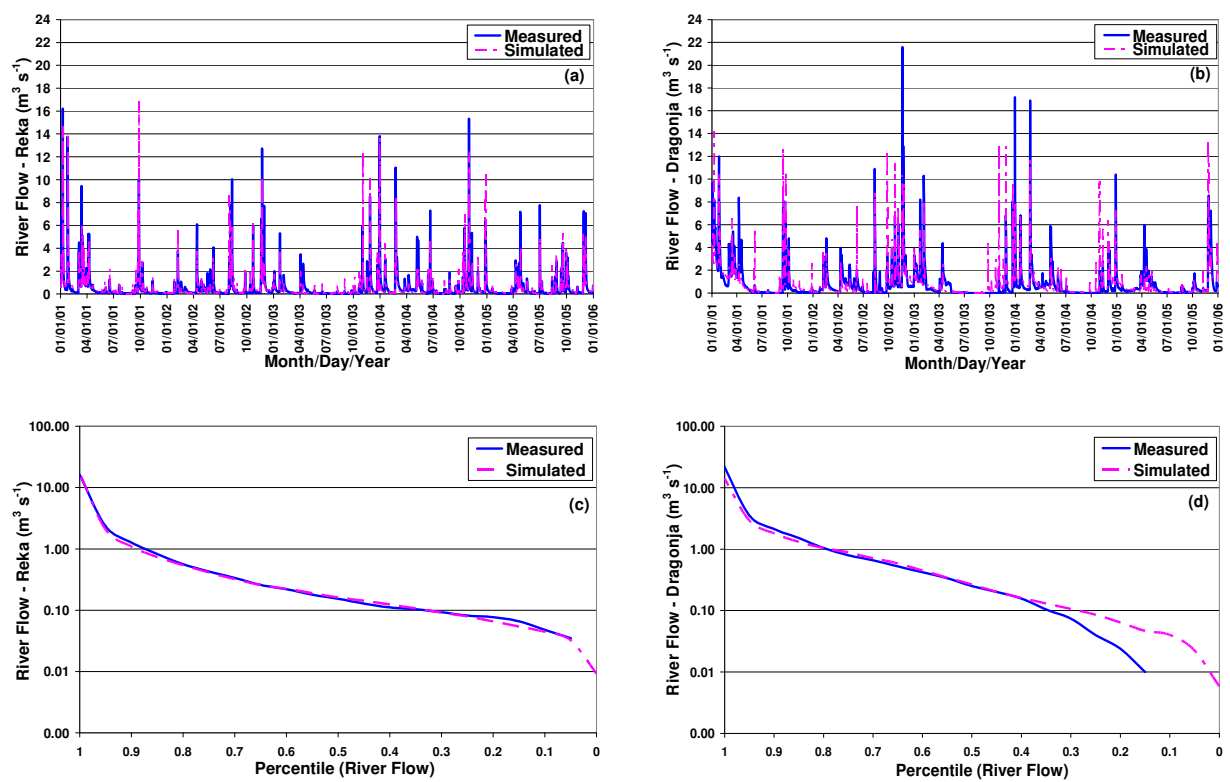

Fig. 2. Comparison between simulated (SWAT) and measured daily flows $\left(\mathrm{m}^{3} \mathrm{~s}^{-1}\right)(\mathrm{a}, \mathrm{b})$ and cumulative distribution (c, d) of daily river flows for the calibration period (2001-2005) 


\subsection{Sediment, nitrogen and phosphorus calibration}

Sediment calibration is essential for the proper $\mathrm{P}$ calibration, as $\mathrm{P}$ is preferentially transported adsorbed on the sediment particles. Parameters used for the calibration were USLE_P, SPCON, SPEXP, CH_EROD, CH_COV. Simulation results for the river Reka show lower $\mathrm{E}_{\mathrm{NS}}=0.23$ and a good result in predicting the variability of $\mathrm{E}_{\mathrm{NSpercentile}}=0.83$ (Table 6). In the case of Dragonja, model achieved good results for $\mathrm{E}_{\mathrm{NS}}=0.70$ and $\mathrm{E}_{\mathrm{NSpercentile}}=0.73$. PBIAS values fall within the category of very good results as deviation is less than $15 \%$ (Moriasi et al., 2007).

Parameters with impact on the N calibration results were FRT_SURFACE, NPERCO, AL1, CMN, HLIFE_NGW. The river Dragonja statistic is lower $\left(\mathrm{E}_{\mathrm{NS}}=0.10, \mathrm{E}_{\mathrm{Nspercentile}}=0.78\right)$ and

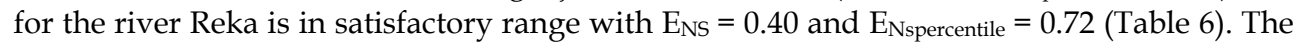
PBIAS results fall into the very good (Dragonja) and satisfactory (Reka) category (Moriasi et al., 2007). The lower performance of the objective functions is connected to data scarcity in the Dragonja catchment with only 73 measurements in 14 years and in river Reka with only one year of daily data. Therefore, it is difficult to say whether the model is a good predictor of nitrate nitrogen $\left(\mathrm{NO}_{3}-\mathrm{N}\right)$ loads and dynamics. Monthly sampling rate leads to inaccurate estimates of the transported loads of nutrients in rivers (Johnes, 2007); especially $\mathrm{NO}_{3}$ - (Harmel et al, 2006).

\subsection{Model performance indicators}

An important step before calibrating sediment and water quality parameters is to look at other model performance indicators. Three main parameters are crop growth, evapotranspiration (ET) and Soil Water Content (SWC), as all of them have a great effect on the water balance. Evapotranspiration is a primary mechanism by which water is removed from the catchment. It depends on air temperature and soil water content. The higher the temperature, the higher is potential evapotranspiration (PET) and consequently ET, if there is enough of water in the soil. A simple monthly water balance between monthly precipitation and PET showed that average monthly water balance in the Reka catchment (station Bilje) is negative between May and August (Fig. 3). In the Dragonja catchment (station Portorož) water balance is negative from April to August (growing season) (Fig. 3).
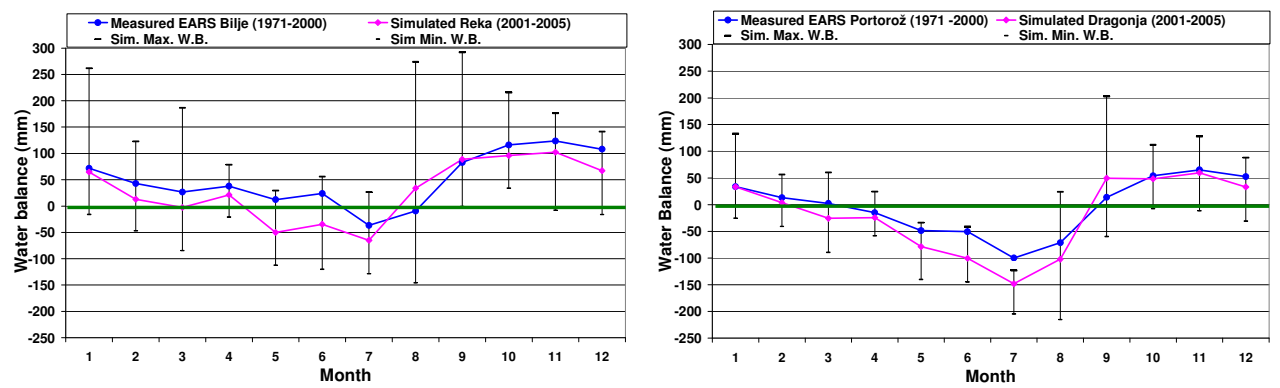

Fig. 3. Comparison of simulated and measured (Environment Agency of Republic of Slovenia - EARS) water balance ( $\mathrm{mm}$ ) for the Reka subcatchments 8 and Dragonja subcatchment 14 


\begin{tabular}{|c|c|c|c|c|c|}
\hline \multirow{2}{*}{\multicolumn{2}{|c|}{$\begin{array}{l}\text { Parameter } \\
\text { Sediment }\end{array}$}} & \multirow{2}{*}{ Default } & \multirow{2}{*}{ Range } & \multicolumn{2}{|l|}{ Calibrated values } \\
\hline & & & & Reka-Kožbanjšček & \multirow{2}{*}{$\begin{array}{l}\text { Dragonja } \\
0,002\end{array}$} \\
\hline 1 & SpCon & 0.0001 & $0.0001-0.01$ & 0.002 & \\
\hline 2 & SpExp & 1 & $1-1.5$ & 1.3 & 1 \\
\hline 3 & Ch_Erod & 0 & $0-1$ & 0.092 & 0,06 \\
\hline 4 & Ch_Cov & 0 & $0.05-0.6$ & 0.1 & 0,1 \\
\hline 5 & USLE_P & 1 & $0-1$ & slope dependent & slope dependent \\
\hline \multicolumn{2}{|c|}{$\mathrm{E}_{\mathrm{NS}}$} & & & 0.23 & 0.70 \\
\hline \multicolumn{2}{|c|}{$\mathrm{E}_{\mathrm{NS}}$ percentile } & & & 0.83 & 0.73 \\
\hline \multicolumn{2}{|c|}{$\mathbf{R}^{2}$} & & & 0.24 & 0.80 \\
\hline \multicolumn{2}{|c|}{ RMSE } & & & 10.35 & 19.81 \\
\hline \multicolumn{2}{|c|}{ PBIAS } & & & -0.15 & -6.33 \\
\hline \multicolumn{4}{|c|}{ Nitrate nitrogen $\left(\mathrm{NO}_{3}-\mathrm{N}\right)$} & & \\
\hline 1 & Nperco & 0.2 & $0.01-1$ & 1 & 0,2 \\
\hline 2 & Al1 & 0.08 & $0.07-0.09$ & 0.071 & 0,08 \\
\hline 3 & $\mathrm{CMN}$ & 0.0003 & $0.0001-0.001$ & - & 0,0001 \\
\hline 4 & HLIFE_NGW & 0 & $0-200$ & - & 0,02 \\
\hline 5 & FRT_surface & 0.2 & $0-1$ & $\begin{array}{l}\text { management } \\
\text { dependent }\end{array}$ & $\begin{array}{l}\text { management } \\
\text { dependent }\end{array}$ \\
\hline \multicolumn{2}{|c|}{$E_{N S}$} & & & 0.40 & 0.10 \\
\hline \multicolumn{2}{|c|}{$E_{N S}$ percentile } & & & 0.72 & 0.78 \\
\hline \multicolumn{2}{|c|}{$\mathbf{R}^{2}$} & & & 0.46 & 0.17 \\
\hline \multicolumn{2}{|c|}{ RMSE } & & & 79.89 & 5.11 \\
\hline \multicolumn{2}{|c|}{ PBIAS } & & & 21.24 & -3.43 \\
\hline \multicolumn{6}{|c|}{ Total phosphorus (TP) } \\
\hline 1 & Pperco & 10 & $10-17.5$ & 15 & 10 \\
\hline 2 & Phoskd & 175 & $100-200$ & 175 & 200 \\
\hline 3 & $\mathrm{Al} 2$ & 0.015 & $0.01-0.02$ & 0.003 & 0,001 \\
\hline 4 & PSP & 0.4 & $0.01-0.7$ & 0.22 & 0,04 \\
\hline 5 & ERORGP & 0 & $0.001-5$ & 0 & 0,003 \\
\hline 6 & $\mathrm{BC} 4$ & 0.35 & $0.01-0.7$ & 0.1 & 0,1 \\
\hline 7 & RS2 & 0.05 & $0.001-0.1$ & 0.1 & 0,1 \\
\hline 8 & RS5 & 0.05 & $0.001-0.9$ & 0.08 & 0,001 \\
\hline 9 & FRT_surface & 0.2 & $0-1$ & $\begin{array}{l}\text { management } \\
\text { dependent }\end{array}$ & $\begin{array}{l}\text { management } \\
\text { dependent }\end{array}$ \\
\hline \multicolumn{2}{|c|}{$\mathrm{E}_{\mathrm{NS}}$} & & & -0.05 & 0.36 \\
\hline \multicolumn{2}{|c|}{ ENS $_{\text {percentile }}$} & & & 0.95 & 0.85 \\
\hline \multicolumn{2}{|c|}{$\mathbf{R}^{2}$} & & & 0.11 & 0.46 \\
\hline \multicolumn{2}{|c|}{ RMSE } & & & 48.17 & 0.18 \\
\hline \multicolumn{2}{|c|}{ PBIAS } & & & 3.43 & 49.21 \\
\hline
\end{tabular}

Table 6. SWAT water quality parameters, their ranges and the final values chosen for the models calibration periods (Reka 2008 - 2009; Dragonja 1994 - 2008) 
Water that enters the soil may move along one of the several different pathways. It may be removed by plant uptake or evaporation; it may percolate past the bottom of the soil profile or may move laterally in the profile. However, plant uptake removes the majority of water that enters the soil profile (Neitsch et al., 2005). The soil water content will be represented correctly if crops are growing at the expected rate and soils have been correctly parameterized. Figure 4 shows the average of HRU for both catchments, with a silt clay soils, with the prevailing surface runoff and slow lateral subsurface flow. Soils exit the field capacity in the spring and return to that state in the autumn (Fig. 4). Soils in the summer are often completely dry with occasional increasing induced by storms.
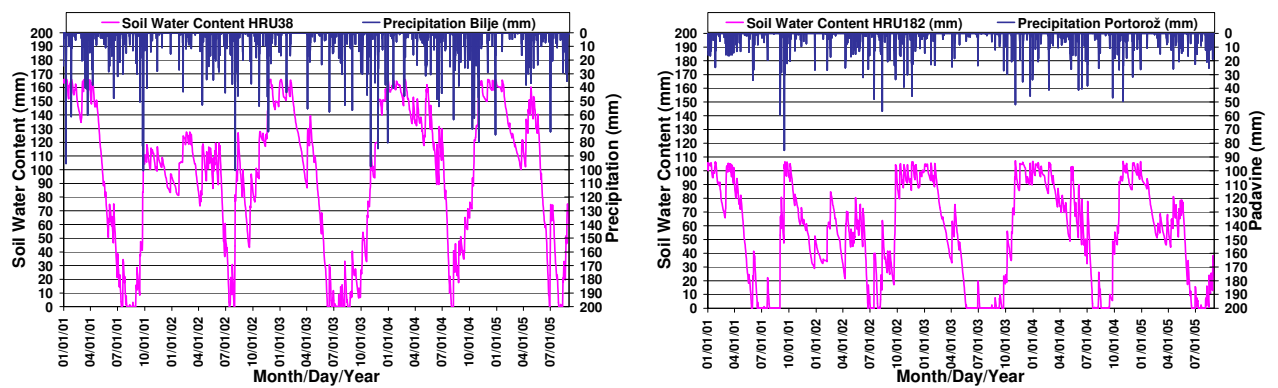

Fig. 4. Comparison of simulated soil water content $(\mathrm{mm})$ for the HRU No. 38 (Reka) and HRU No. 182 (Dragonja) and observed precipitation $(\mathrm{mm})$ in the calibration period (2001-2005)

The plant growth component of SWAT is a simplified version of the plant growth model. Phenological plant development is based on daily accumulated heat units, leaf area development, potential biomass is based on a method developed by Monteith, a harvest index is used to calculate yield, and plant growth can be inhibited by temperature, water, N or P stress. (Neitsch et al., 2005). In the crop database a range of parameters can be changed to meet the requirements for optimal plant growth. We used default SWAT database parameters that were additionally modified (Frame, 1992). An example crop growth profile for development of leaf area index (LAI) and plant biomass (BIOM) for vineyard is presented on figure 5 .

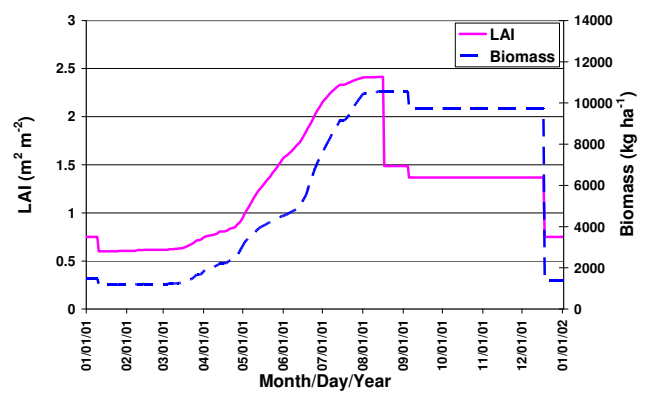

Fig. 5. Simulated vineyard biomass growth $\left(\mathrm{kg} \mathrm{ha}^{-1}\right)$ and leaf area index $\left(\mathrm{m}^{2} \mathrm{~m}^{-2}\right)$ for the HRU No. 38 in the river Reka catchment 


\section{Agri-environmental scenarios}

The aim of this scenario was to investigate possible effects of the agri-environmental measures on the river water quality. To achieve the aim seven different scenarios were applied to the study area EVP, EKO20, EKO100, S35, S50, STV35, ETA.

The field erosion buffer strips scenario (EVP) is a function of how to minimize influences of diffuse pollution resulting from agricultural activities without drastic management changes. They are planted or indigenous bands of vegetation that are situated between source areas and receiving waters to reduce surface runoff velocities and to remove pollutants from surface and subsurface runoff. The effectiveness of strips is closely correlated with their slope and width (Dillaha et al., 1989). An option of $3 \mathrm{~m}$ wide strips was modelled on all arable (AGRC, AGRR), vineyard (VINE), orchard (ORCI, ORCE) in olive grove (OLEA) HRUs.

Organic farming scenarios on $20 \%$ of the area (EKO20) and on the $100 \%$ area (EKO100) aim to reduce the use of mineral fertilizers and to reduce the intensity of production. Special organic rotations with green manure and composted farmyard manure were created. The lack of $\mathrm{P}$ was compensated with the use of triple-superphosphate that is allowed in organic production. Both organic scenarios were designed to ensure normal production for the market.

Steep meadows, being an agricultural landscape, should be cut regularly, but due to the steep slopes and the associated costs and risks, are abandoned and overgrown. Scenarios having steep meadows with slope inclination above $35 \%$ (S35) and $50 \%$ (S50) should prevent overgrowth. To verify the effects of scenarios on water quantity and nutrients transport, meadows (TRAV) of both case studies located on slopes greater than $35 \%$ and $50 \%$ were changed into the forest (FRSD) (Fig. 6). In the S35 scenario $18 \%$ (Reka) and $3.6 \%$ (Dragonja) of grassland was changed into forest, which is equivalent to $1.43 \%$ (Reka) and $0.67 \%$ (Dragonja) of the total catchments. In the S50 scenario only $2 \%$ (Reka) and $0.3 \%$ (Dragonja) of grassland was changed into forest, which is equivalent to $0.16 \%$ (Reka) and $0.06 \%$ (Dragonja) of the total catchments.
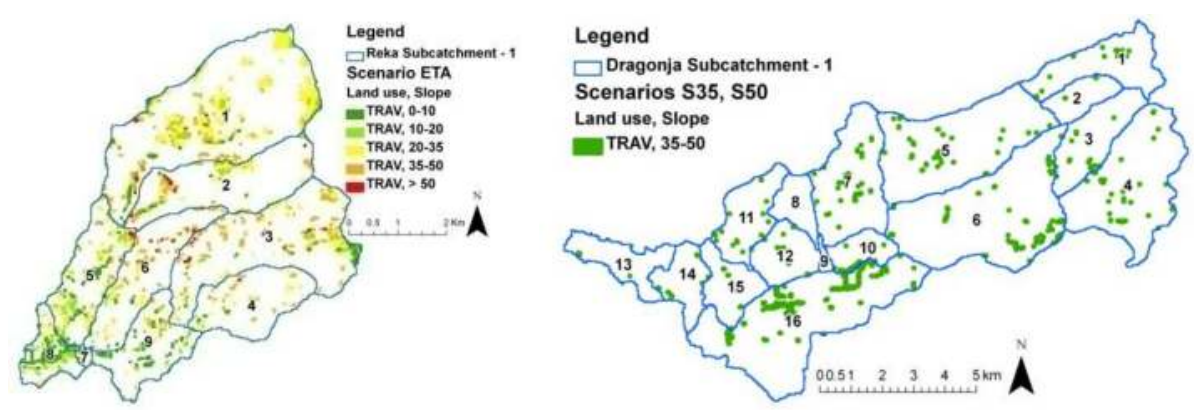

Fig. 6. Hydrological response units with the grassland land use (TRAV) and slopes greater than $35 \%$ and $50 \%$ for the Reka and Dragonja catchment

Conservation of vineyards on steep slopes has proved to be difficult because of unprofitable production. Economic reasons were followed by a trend of wine production abandonment. 
In the steep vineyards scenario (STV35), all vineyards on the slopes greater than $35 \%$ were changed into forest, to verify the environmental impact of abandonment of vineyards on steep slopes (Fig. 7). In the STV35 scenario, 17 \% (Reka) and $1.4 \%$ (Dragonja) of grassland is changed into forest, which is equivalent to 3.93\% (River) and $0.06 \%$ (Dragonja) of the total catchments.
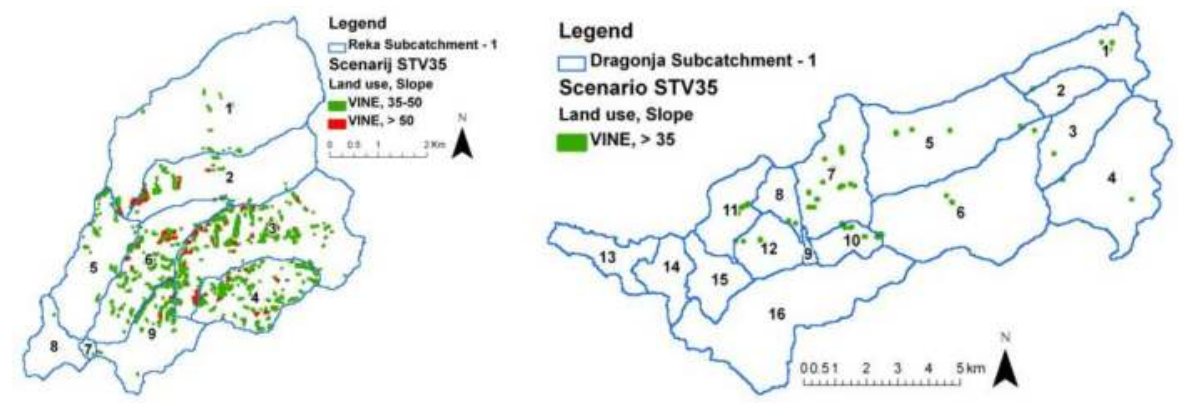

Fig. 7. Hydrological response units with the vineyard land use (VINE) and slopes greater than $35 \%$ for the Reka and Dragonja catchment

Extensive grassland scenario (ETA) objective was to determine what would be the impact on water quantity and quality, if the whole grassland would be overgrown with forest. Extensive grassland use with one cutting is widespread in both areas. Whole grassland in the Reka $(8 \%)$ and Dragonja (18\%) catchments area was turned into a forest (Fig. 8).
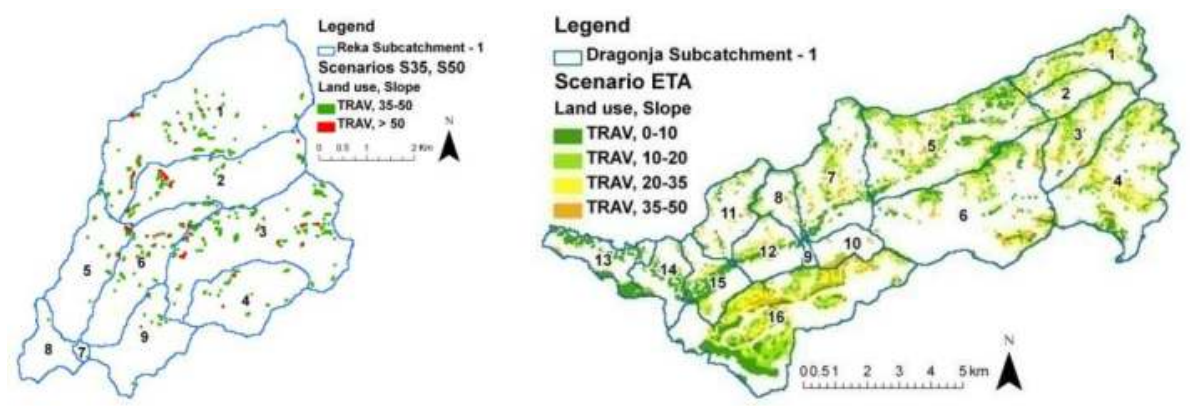

Fig. 8. Hydrological response units with the grassland land use (TRAV) and slope classes for the Reka and Dragonja catchment

\section{Results and discussion}

The base scenario indicates a high average annual variability in the transport of the sediment, total nitrogen (TN) and total phosphorus (TP) in the river flow (Table 7). The standard deviations for the Reka subcatchment 8 reveal that the sediment, TN and TP 2/3 of transported quantities are expected in the interval 1,844 $\pm 1,075 \mathrm{t}_{\text {sediment year }}{ }^{-1}$, $88,728 \pm 63,255 \mathrm{~kg} \mathrm{TN}_{\text {year }}{ }^{-1}$ and $3,489 \pm 2,993 \mathrm{~kg} \mathrm{TP} \mathrm{year}^{-1}$ and for the Dragonja subcatchment 14 in the interval 4,804 $\pm 1,576$ t sediment year $\mathrm{t}^{-1}, 163,763 \pm 98,949 \mathrm{~kg}$ TN year1 and $3,489 \pm 11,742 \mathrm{~kg}$ TP year-1. 


\begin{tabular}{|c|c|c|c|c|c|}
\hline Catchment/subcatchment & Average & Median & $\begin{array}{l}\text { Standard } \\
\text { deviation }\end{array}$ & Min. & Max. \\
\hline \multicolumn{6}{|l|}{ Flow $\left(m^{3} \mathrm{~s}^{-1}\right)$} \\
\hline Reka/8 & 0.57 & 0.56 & 0.21 & 0.27 & 1.00 \\
\hline Dragonja/14 & 0.80 & 0.78 & 0.21 & 0.42 & 1.11 \\
\hline \multicolumn{6}{|l|}{ Sediment ( $t$ year-1) } \\
\hline Reka/8 & 1,844 & 1,576 & 1,075 & 571 & 4,185 \\
\hline Dragonja/14 & 4,804 & 4,934 & 1,576 & 1,917 & 7,734 \\
\hline \multicolumn{6}{|l|}{ Total nitrogen (kg year $\left.{ }^{-1}\right)$} \\
\hline Reka/8 & 88,728 & 74,260 & 63,255 & 33,376 & 278,227 \\
\hline Dragonja/14 & 163,763 & 134,801 & 98,949 & 59,922 & 406,330 \\
\hline \multicolumn{6}{|l|}{ Total phosphorus (kg year-1) } \\
\hline Reka/8 & 3,489 & 2,729 & 2,993 & 947 & 11,742 \\
\hline Dragonja/14 & 2,420 & 1,950 & 1,447 & 896 & 6,009 \\
\hline
\end{tabular}

Table 7. Average annual flow $\left(\mathrm{m}^{3} \mathrm{~s}^{-1}\right)$ and river load of sediment $(\mathrm{t}$ year-1), total nitrogen and total phosphorus $\left(\mathrm{kg} \mathrm{year}^{-1}\right)$ for the Reka subcatchment 8 and Dragonja subcatchment 14 (1994-2008)

\subsection{River flow}

Changes in average annual flow between base and agri-environmental scenarios are minimal for both catchments for the research period. Maximum changes on an annual basis are less than $0.5 \%$ (Table 8 ) and on a monthly basis close to 1\% (Reka) and 5\% (Dragonja) (Fig. 9). Student t-statistics for average annual flows reveal that the results of the agrienvironmental scenarios are not statistically different from the base scenario (Table 9).

\begin{tabular}{|l|c|c|c|c|c|c|c|c|}
\hline \multirow{2}{*}{$\begin{array}{l}\text { Catchment/ } \\
\text { subcatchment }\end{array}$} & EVP & EKO20 & EKO100 & S35 & S50 & STV35 & ETA \\
\cline { 2 - 8 } & Ever Flow \\
\hline Reka/8 & 0.00 & 0.09 & 0.04 & 0.02 & 0.00 & 0.17 & 0.16 \\
\hline Dragonja/14 & 0.00 & -0.32 & 0.36 & 0.00 & 0.00 & 0.00 & 0.09 \\
\hline Sediment \\
\hline Reka/8 & -14.93 & -4.95 & -25.42 & -0.85 & -0.05 & -2.28 & -3.12 \\
\hline Dragonja/14 & -31.95 & -20.82 & -20.92 & -2.26 & -0.05 & -0.01 & -52.96 \\
\hline Total nitrogen & \multicolumn{7}{|c|}{} & \\
\hline Reka/8 & -2.67 & 9.00 & -1.91 & -0.43 & -0.02 & -5.15 & -2.32 \\
\hline Dragonja/14 & -1.46 & 12.51 & 3.71 & -0.22 & -0.01 & 0.00 & -6.63 \\
\hline Total phosphorus & -14.15 & 9.28 & -26.15 & -0.58 & -0.04 & -2.44 & -3.45 \\
\hline Reka/8 & -3.28 & 9.90 & 1.39 & -0.29 & 0.00 & 0.00 & -8.58 \\
\hline Dragonja/14 &
\end{tabular}

Table 8. Impacts (change in \%) of agri-environmental scenarios on the river flow, sediment load, total nitrogen and total phosphorus load in the watercourse; compared to the baseline scenario 

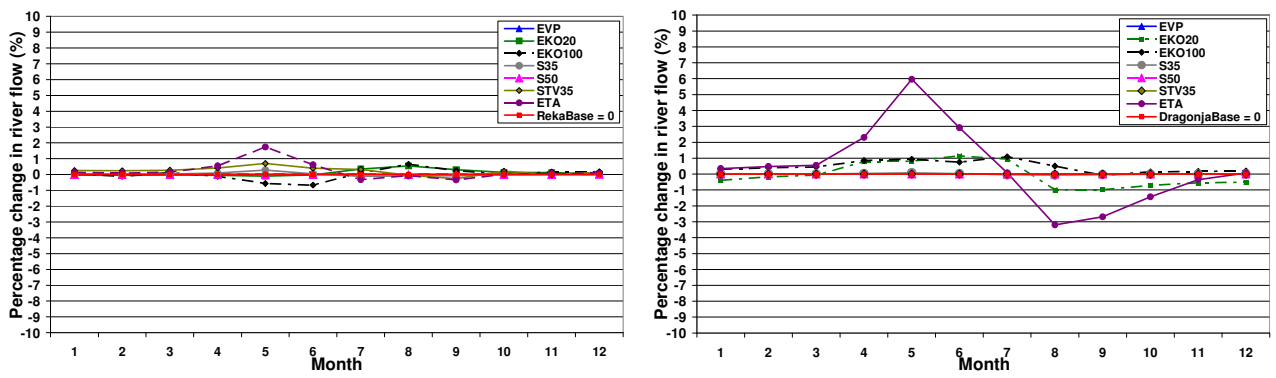

Fig. 9. Change in average monthly flow (\%) between the base (Base $=0)$ and agri-environmental scenarios for the Reka subcatchment 8 and Dragonja subcatchment 14 (1994-2008)

\begin{tabular}{|c|c|c|c|c|c|c|c|c|}
\hline \multirow[b]{3}{*}{ Scenario } & \multicolumn{8}{|c|}{$\begin{array}{l}\text { Student } t \text {-test (Significance level } 0.05 \text { ) } \\
\text { Student distribution of the sample with } n-1 \text { degrees of freedom } \\
\alpha=0.025, S P=14, t_{\alpha}=2.145\end{array}$} \\
\hline & \multicolumn{4}{|c|}{ Reka - subcatchment 8} & \multicolumn{4}{|c|}{ Dragonja - subcatchment 14} \\
\hline & Flow & Sediment & TN & TP & Flow & Sediment & TN & TP \\
\hline EVP & 0.000 & -1.214 & -0.148 & -0.712 & 0.000 & -5.630 & -0.122 & -0.215 \\
\hline EKO20 & 0.009 & -0.348 & 0.448 & 0.389 & -0.047 & -3.056 & 0.750 & 0.603 \\
\hline EKO100 & 0.005 & -2.435 & -0.105 & -1.439 & 0.053 & -3.023 & 0.209 & 0.080 \\
\hline S35 & 0.002 & -0.057 & -0.023 & -0.027 & 0.000 & -0.274 & -0.014 & -0.019 \\
\hline S50 & 0.000 & -0.004 & -0.001 & -0.002 & 0.000 & -0.006 & -0.001 & 0.000 \\
\hline STV35 & 0.018 & -0.157 & -0.281 & -0.112 & 0.000 & -0.001 & 0.000 & 0.000 \\
\hline ETA & 0.018 & -0.216 & -0.127 & -0.159 & 0.013 & -14.386 & -0.450 & -0.594 \\
\hline
\end{tabular}

Note: The results of the scenarios are statistically significantly different from the base scenario, if the value of Student $t$-test exceeds $t_{\alpha}=2.145$. If the value is negative, scenario is reducing the quantities in the river flow, and vice versa.

Table 9. Review of statistically significant results of Student t-statistics for average annual flow and average annual load of sediment, total nitrogen and total phosphorus

\subsection{Sediment}

Impacts of agri-environmental scenarios EVP, EKO20, EKO100, S35, S50, STV35, ETA on an average annual load of sediment transported with the flow are evident for certain scenarios (Table 8). Statistically significant changes in the Reka catchment have been calculated for the EKO100 scenario, while the EVP scenario result is slightly lower to be statistically significantly different (Table 9). The river Dragonja results show that changes in the scenarios EVP, EKO20, EKO100 and ETA are statistically significantly different from the base scenario (Table 9). The biggest differences between scenarios in transported sediment load are in autumn and winter months, when the loads for scenarios EKO100 (Reka) and ETA (Dragonja) get considerably reduced (Fig. 10). 

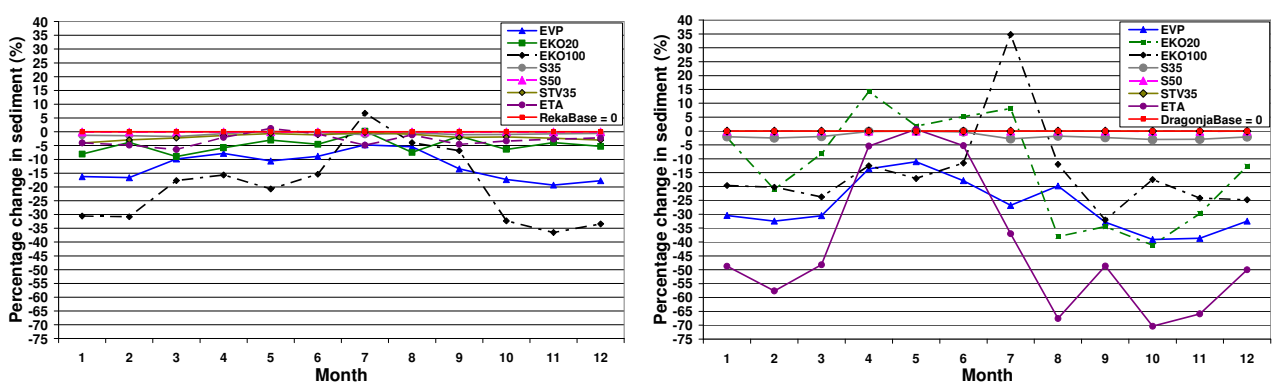

Fig. 10. Change in average monthly river loads of sediment $(\%)$ between the base $($ Base $=0)$ and agri-environmental scenarios for the Reka subcatchment 8 and Dragonja subcatchment 14 (1994-2008)

\subsection{Total nitrogen}

The effect of agri-environmental scenarios on the annual TP transport in the river flow has proved to be negligibly small, due to the small proportion of land on which the scenarios were set up (Table 8). The results of the agri-environmental scenarios for the TN transport in both catchments are not statistically significantly different from the base scenario (Table 9). Large monthly variations in the loads of TP transported were typical for the scenarios with higher levels of organic matter (EKO20, EKO100, ETA) (Fig. 11). The decomposition of the organic matter is difficult to control, monitor and predict. However, on an annual basis, the variation between months are equalized.
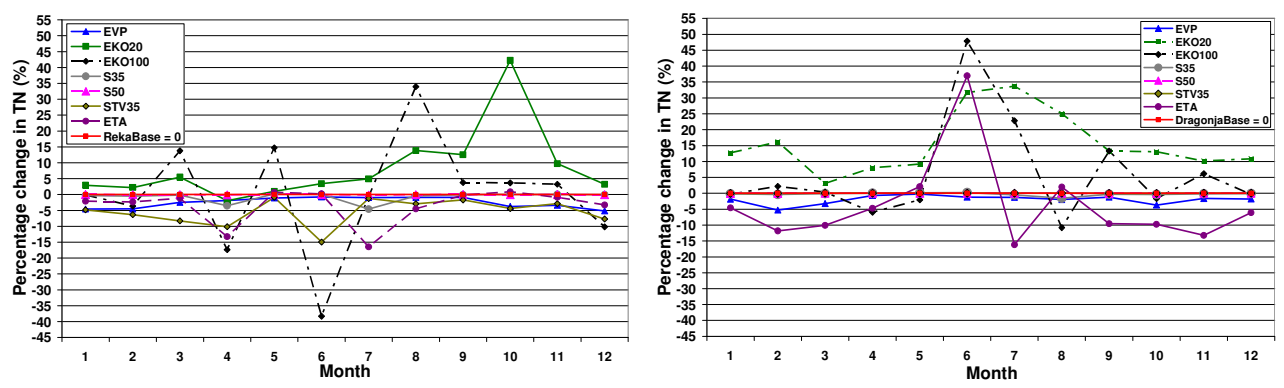

Fig. 11. Change in average monthly river loads of total nitrogen (\%) between the base $($ Base $=0)$ and agri-environmental scenarios for the Reka subcatchment 8 and Dragonja subcatchment 14 (1994-2008)

\subsection{Total phosphorus}

The effects of agri-environmental scenarios on the TP transport in the stream are low (Table 8) and may be observed in scenarios EKO 100 and EVP (Reka) and ETA (Dragonja) (Fig. 12). Student t-statistics for average annual TP load in both catchments are not statistically significantly different (Table 9). In case of Rivers, maximum difference between the scenarios resulting in cooler and wetter period of the year, and in the Dragonja catchment, in the warmer and more stormy period. 

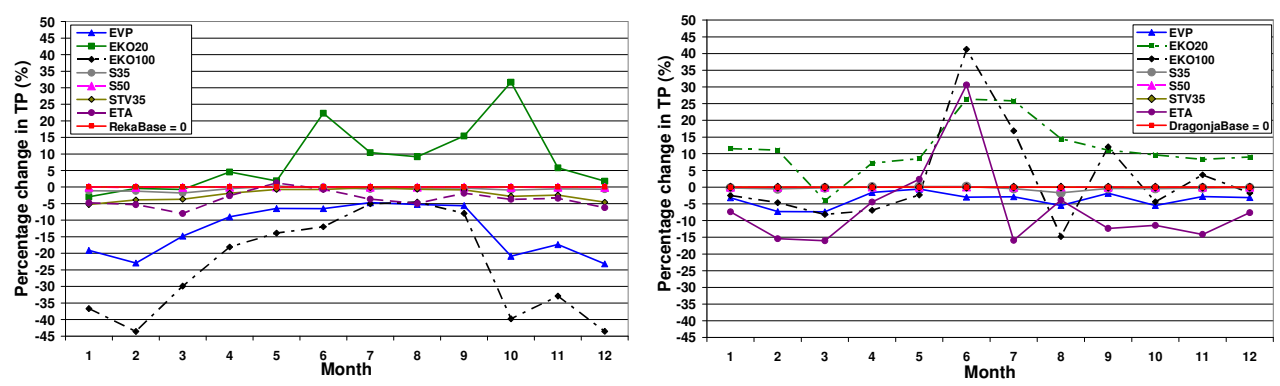

Fig. 12. Change in average monthly river loads of total phosphorus (\%) between the base $($ Base $=0)$ and agri-environmental scenarios for the Reka subcatchment 8 and Dragonja subcatchment 14 (1994-2008)

\subsection{Scenario evaluation}

The evaluation of impacts of the agri-environmental scenarios on the sediment and nutrients transport processes on the catchment level was performed in the light of the EU Water Framework Directive (WFD 2000/60/ES) and Republic of Slovenia legislation. Both set guide concentrations with the purpose of limiting impacts of excessive levels on flora and fauna in the rivers. When interpreting the concentrations we need to have in mind the geological and pedological characteristics of the catchment. There is also the question of whether to consider set guide levels for the rivers that do not represent an economic interest (Lohse, 2008), however rivers are not only economic asset. When recommending possible agri-environmental mitigation measures to deliver water quality improvements, careful evaluation and prioritization of each measure has to be performed according to its positive and negative issues on the environment, agriculture, social life and economy (Bockstaller et al., 2009; Everard, 2004; Glavan et al., 2011).

The results of the scenarios demonstrate that in the Reka and Dragonja catchments major problems with the concentrations of $\mathrm{NO}_{3}$ - and $\mathrm{TP}$ are excluded, as both are lower than the limit values (Table 10). Nevertheless, the results reveal the difficult path to achieve the recommended value for sediment in both catchments, especially in the case of the river Reka catchment. With the realization of agri-environmental scenarios for the Dragonja catchment, particularly the EVP and ETA, we could expect reduction of the sediment concentration below the recommended level and consequently water quality improvements. In the Dragonja catchment, the guide concentration of $25 \mathrm{mg} \mathrm{l}^{-1}$ was reached with the scenarios EVP, EKO20, EKO10 and ETA. However, in the Reka catchment, scenarios sediment reductions are not sufficient to reduce the concentration below the guide level. This leads us to thinking, that catchment is dominated by certain land use (vineyard) and soils, which have a negative impact on the river concentrations (Komac \& Zorn, 2007; Petek, 2007; Volk et al., 2009).

The EKO100 scenario is considering the low proportion of land involved in organic production in research areas almost impracticably, since it would require too much labour-intensive work, which results in a higher final price of the crop. Organic production is advised in the areas with long-term organic fertilization where soils were 
sufficiently enriched with organic matter and nutrients to supply plants for a several decades (Mihelič et al., 2009). In the Dragonja catchment, which is subject to a high degree of afforestation, the scenario EVP reflected in the significant concentration reduction below the recommended value. We used 3 meters wide vegetation bands that have reflected a $14 \%$ (Reka) and $31 \%$ (Dragonja) reduction of sediment in the watercourse, but with broader bands, an even greater impact could be achieved. For the effectiveness of the bands, the identification of critical points is important (Garen \& Moore, 2005; Wolfe, 2000). A small proportion of the area can have a significant impact on the sediment, $\mathrm{N}$ and $P$ loads in the watercourses.

\begin{tabular}{|c|c|c|c|c|c|c|c|}
\hline & & \multicolumn{6}{|c|}{ Average annual concentration ( $\mathrm{mg} \mathrm{l}^{-1}$ ) } \\
\hline & & \multicolumn{3}{|c|}{$\begin{array}{l}\text { DRAGONJA - subcatchment } 14 \\
\text { (Podkaštel 9300) - cyprinid river }\end{array}$} & \multicolumn{3}{|c|}{$\begin{array}{l}\text { REKA - subcatchment } 5 \\
\text { (Neblo 8700) - salmonid river }\end{array}$} \\
\hline & & Sediment & Nitrate & TP & Sediment & Nitrate & TP \\
\hline \multicolumn{2}{|c|}{ Measured } & 29.3 & 2.7 & 0.043 & 32.6 & 2.7 & 0.109 \\
\hline \multirow{7}{*}{ 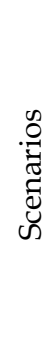 } & EVP & 19.9 & 2.6 & 0.042 & 28.8 & 2.7 & 0.100 \\
\hline & EKO20 & 23.2 & 2.7 & 0.045 & 31.1 & 2.5 & 0.121 \\
\hline & EKO100 & 23.2 & 2.6 & 0.044 & 27.6 & 2.9 & 0.092 \\
\hline & S35 & 28.6 & 2.7 & 0.043 & 32.2 & 2.7 & 0.108 \\
\hline & S50 & 29.3 & 2.7 & 0.043 & 32.6 & 2.7 & 0.109 \\
\hline & STV35 & 29.3 & 2.7 & 0.043 & 32.1 & 2.6 & 0.108 \\
\hline & ETA & 13.8 & 2.6 & 0.039 & 30.6 & 2.5 & 0.104 \\
\hline
\end{tabular}

Limit and guide concentrations $\left(\mathrm{mg} \mathrm{l}^{-1}\right)$ set by EU directives and Slovenian regulations: Sediment (river) $25 \mathrm{mg} \mathrm{l}^{-1}$; Nitrate (NO3-) in drinking water $50 \mathrm{mg} \mathrm{l}^{-1}$ and in surface water 14,08 - 30,8 (very good state) and 28,6 - 41,8 mg 1-1 (good state); Total phosphorus (TP) for salmonid waters $0,2 \mathrm{mg} \mathrm{l}^{-1}$ and for cyprinid waters $\mathbf{0 , 4} \mathbf{~ m g ~}^{-1}$.

Table 10. Impacts of the alternative scenarios on the average annual concentration $\left(\mathrm{mg} \mathrm{l}^{-1}\right)$ of the sediment, nitrate and total phosphorus

Following the trend of afforestation of agricultural land, the ETA scenario could become practicable, under which all grassland (18\%) would be overgrown by forest. However, such a scenario is not viable, since larger farmers round up their vineyards and olive groves and reduce overgrowth. However, this process is considerably slower than natural afforestation, which has affected the water cycle and erosion processes in the last decade (Globevnik, 2001). Sediment reductions in the catchment are expected with progressive land abandoned with afforestation and with parallel establishment of buffer zones on larger agriculturally rounded areas. The negative effect of erosion buffer zones is an exclusion of a certain percentage of agricultural land from agricultural production. At $3 \mathrm{~m}$ wide buffer zones on 1 ha of land $\left(10,000 \mathrm{~m}^{2}\right)$ the loss of the land in production would be $12 \%\left(1,200 \mathrm{~m}^{2}\right)$. An important element, which partially contributes to increased sediment loads in the river Dragonja are cliffs and steep eroded slopes without vegetation, which are eroded at the foothills by the river and torrential tributaries. 
To achieve improvements in water quality in the two research catchments the use of a combination of several measures and a close cooperation with all key stakeholders (environmental, agricultural, spatial planning) would be necessary.

\section{Conclusions}

The application of the SWAT model in the Reka and Dragonja catchment has demonstrated that SWAT is able to represent the hydrological behaviour of this heterogeneous catchments and rivers. Within the constraints of the available data the model was able to represent the sediment and nutrients loads, concentrations and cumulative distributions. However, there are a number of issues that the model results can demonstrate as important in the diffuse water pollution control with agri-environmental measures.

1. Research process can demonstrate that because of the lack of monitoring and limited data on sediment, $\mathrm{N}$ and $\mathrm{P}$ concentrations, proper calibration or validation of the model would not be possible. Mixed sampling frequency on a monthly or fortnightly basis can provide the basis for imprecise estimates of nutrient loadings in rivers.

2. Although the simulated crops in the model can grow well and therefore taking up nutrients appropriately, the actual on-site spatial distribution of crops, crop rotations and actual management practices (sowing, harvest and fertiliser application dates and rates) are usually not known. These uncertainties further combine with those uncertainties in the spatial and attribute soil data, which can have an important influence on overall contribution to pollution and successful implementation of environmental measures.

3. As an important element of the catchment modelling is detailed analysis of point sources as in certain study areas can represent prevailing source of $\mathrm{N}$ and $\mathrm{P}$ in the watercourses.

4. Temporal aggregation of model outputs can improve the performance metrics for all the river outputs, including $\mathrm{NO}_{3}$. Temporal aggregation is appropriate to simplify model outputs for those variables, which are adequately simulated at daily level and underpinned by appropriate process representation and model parameterization. This demonstrates the importance of ascertaining the reasons for the use of temporal aggregation in modelling studies.

5. There are important limitations to the treatment of edge of field filter strips within SWAT, which may over-estimate their efficiency of the EVP scenario. The SWAT algorithms relate the fraction of the nutrient load trapped by the buffer to the buffer width, so that additional factors such as slope, vegetation type, soil type and presence of under-drainage are not included. SWAT simulates reduction in pollutant transport across the entire length of a buffer strip, while in reality, as surface flow can concentrate at certain points alongwith buffer strips. SWAT assumes that buffer strips capture the range of particle sizes equally. However, buffer strips may trap coarser sediment with lower $\mathrm{P}$ concentrations, suggesting that the finer fraction, enriched in TP, may preferentially pass through the buffers towards river channels.

6. Base flow represents an important pathway for the transport of dissolved contaminants from the landscape to surface water receptors. The delivery of surface water targets will require the integrated management of land, groundwater base flow and surface water systems. However, SWAT has all the tools and options for setting the initial conditions 
in the model, which can lead to appropriate modelling of nutrients pathways and to account for the nutrient lag times in the groundwater.

7. Physical landscape spatial variability within catchments (topography, soils, land use, land management etc.) have important influence on the model results. This means that pollutant sources and loads are not evenly distributed in space. Rather than impose blanket agri-environmental measures in the model, it is better to target key source areas or HRU combinations that deliver excessive loads.

8. The scenarios assume that all farmers in the catchment take up the structural measures or the changes in land use and management uniformly. However, field work shows that this is not the case. A close cooperation with all key stakeholders on local, regional, national and transnational level and financial support, like EU Common Agriculture Policy, which enable areas to develop in a sustainable way, is necessary.

At the end of this chapter we would like to increase awareness that model results and their interpretation by the modeller must lead to constructive discussion, which aims to achieve and maintain good water quality in research catchments, which is the objective of the Water Framework Directive and other legislation related to water.

\section{Acknowledgments}

Financial support for this study was provided by the Slovenian Research Agency founded by the Government of the Republic of Slovenia. Contract number: 1000-06-310163.

\section{References}

Abbaspour, K.C.; Yang, J.; Maximov, I.; Siber, R.; Bogner, K.; Mieleitner, J.; Zobrist, J. \& R. Srinivasan (2007). Modelling hydrology and water quality in the pre-alpine/alpine Thur watershed using SWAT. Journal of Hydrology, Vol.333, pp. 413-430

Arnold, J.G.; Srinivasan, R.S.; Muttiah, R.S. \& Williams, J.R. (1998). Large area hydrological modelling and assessment Part I: Model development. Journal of the American Water Resources Association, Vol.34, No.1, pp. 73-89

Bockstaller, C.; Guichard, L.; Makowski, D.; Aveline, A.; Girardin, P. \& Plantureux, S. (2009). Agri-environmental indicators to assess cropping and farming systems - A review. Agronomy for Sustainable Development, Vol.28, pp. 139-149

Bowatte, S.; Tillman, R.; Carran, A. \& Gillingham, A. (2006). Can phosphorus fertilisers alone increase levels of soil nitrogen in New Zeland hill country pastures? Nutrient Cycling in Agroecosystems, Vol.75, pp. 57-66

Bracmort, K.S.; Arabi, M.; Frankenberger, J.R.; Engel, B.A. \& Arnold, J.G. (2006). Modelling long-term water quality impact of structural BMPs. Agricultural Society of Agricultural and Biological Engineers, Vol.49, No.2, pp. 367-374

Buda, A.R.; Kleinman, P.J.A; Srinivasan, M.S.; Bryant, R.B. \& Feyereisen, G.W. (2009). Effects of Hydrology and Field Management on Phosphorus Transport in Surface Runoff. Journal of Environmental Quality, Vol.38, pp. 2273-2284

Čarman, M.; Mikoš, M. \& Pintar, M. (2007). Različni vidiki erozije tal v Sloveniji = Different aspects of soil erosion in Slovenia. In: Strategija varovanja tal v Sloveniji: Zbornik referatov, M. Knapič, (Ed.), 39-50, Pedološko društvo Slovenije = Slovenian Soil science Society, Ljubljana 
Di Luzio, M.; Arnold, J. G. \& Srinivasan, R. (2005). Effect of GIS data quality on small watershed streamflow and sediment simulations. Hydrolgical Processes, Vol.19, No.3, pp. 629-650

Dillaha, T.A.; Reneau, R.B.; Mostaghimi, S.\& Lee, D. (1989). Vegetative filter strips for agricultural nonpoint source pollution control. Transactions of the ASAE, Vol.32, No.2, pp. 513-519

Dymond, R.; Lohani, V.; Kibler, D.; Bosch, D.; Rubin, E.J.; Dietz, R.; Chanat, J.; Speir, C.; Shaffer, C.A.; Ramakrishnan, N. \& Watson, L.T. (2003). From landscapes to waterscapes: A PSE for landuse change analysis. Engineering with Computers, Vol.19, pp 9-25

Everard, M. (2004). Investing in sustainable catchments. Science of the Total Environment, Vol.324, pp. 1-24

EUSOILS (2004). Nature and extent of soil erosion in Europe, European Commisson, 2. June 2011, Available from http://eusoils.jrc.ec.europa.eu/esdb_archive/pesera/pesera_cd/

Frame, J. (1992). Improved grassland management. Farming Press Books, Wharfedale

Garen, D.C. \& Moore, D.S. (2005). Curve number hydrology in water quality modeling: uses, abuses, and future directions. Journal of the American Water Resources Association, Vol.41, No.6, pp. 1491-1492

Gassman, P.W.; Reyes, M.R.; Green, C.H. \& Arnold, J.G. (2007). The soil and water assessment tool: Historical development, applications, and future research direction. Transactions of the ASABE, Vol.50, No.4, pp. 1211-1250

Glavan, M. \& Pintar, M. (2010). Impact of point and diffuse pollution sources on nitrate and ammonium ion concentrations in the karst-influenced Temenica river. Fresenius Environmental Bulletin, Vol.19, No.5A, pp. 1005-1014

Glavan, M.; White, S. \& Holman, I. (2011). Evaluation of river water quality simulations at a daily time step - Experience with SWAT in the Axe Catchment, UK. CLEAN - Soil, Air, Water, Vol.39, No.1, pp. 43-54

Globevnik, L. (2001). Celosten pristop $k$ urejanju voda v porečjih $=$ An integrated approach to water management in river basins. Doctoral thesis. University of Ljubljana, Ljubljana

Harmel, R.D.; Potter, S.; Ellis, P.; Reckhow, K.; Green, C.H. \& Haney, R.L. (2006). Compilation of measured nutrient load data for agricultural land uses in the US. Journal of American Water Resources Association, Vol.42, pp. 1163-1178

Hatch, L.K.; Mallawatantri, A.; Wheeler, D.; Gleason, A.; Mulla, D.; Perry, J.; Easter, K.W.; Smith, R.; Gerlach, L. \& Brezonik, P. (2001). Land management at the major watershed-agroecoregion intersection. Journal of Soil and Water Conservation, Vol.56, No.1, pp. 44-51

Hejzlar, J.; Anthony, S.; Arheimer, B.; Behrendt, H.; Bouraoui, F.; Grizzetti, B.; Groenendijk, P.; Jeuken, M.; Johnsson, H.; Lo Porto, A.; Kronvang, B.; Panagopoulos, Y.; Siderius, C.; Silgram, M.; Venohrd, M. \& Žaloudíka, J. (2009). Nitrogen and phosphorus retention in surface waters: an inter-comparison of predictions by catchment models of different complexity, Journal of Environmental Monitoring, Vol.11, pp. 584593

Henriksen, H. J.; Troldborg, L.; Nyegaard, P.; Sonnenborg, O. T.; Refsgaard, J. C. \& Madsen, B. (2003). Methodology for construction, calibration and validation of a national hydrological model for Denmark. Journal of Hydrology, Vol.280, pp. 52-71 
Johnes, P.J. (2007). Uncertainties in annual riverine phosphorus load estimation: Impact of load estimation methodology, sampling frequency, baseflow index and catchment population density. Journal of Hydrology, Vol.332, pp. 241-258

Khan, F.A \& Ansari, A.A (2005). Eutrophication: An Ecological Vision. The Botanical Review, Vol.71, No.4, pp. 449-482

Komac, B. \& Zorn, M. (2007). Probability modelling of landslide hazard. Acta geographica Slovenica, Vol.47, No.2, pp. 139-169

Kronvang, B.; Behrendt, H.; Andersen, H.; Arheimer, B.; Barr, A.; Borgvang, S.; Bouraoui, F.; Granlund, K.; Grizzetti, B.; Groenendijk, P.; Schwaiger, E.; Hejzlar, J.; Hoffman, L.; Johnsson, H.; Panagopoulos, Y.; Lo Porto, A.; Reisser, H; Schoumans, O.; Anthony, S.; Silgram, M.; Venohr, M. \& Larsen, S. (2009a). Ensemble modelling of nutrient loads and nutrient load partitioning in 17 European catchments. Journal of Environmental Monitoring, Vol.11, pp. 572-583

Kronvang, B.; Borgvang, S. A. \& Barkved, L. J. (2009b). Towards European harmonised procedures for quantification of nutrient losses from diffuse sources - the EUROHARP project. Journal of Environmental Monitoring, Vol.11, No.3, pp. 503-505

Krysanova, V. \& Arnold, J.G. (2008). Advances in ecohydrological modelling with SWATa review. Hydrological Sciences-Journal des Sciences Hydrologiques, Vol.53, No.5, pp. 939-947

Kummu, M.; Sarkkula, J.; Koponen, J. \& Nikula, J. (2006). Ecosystem Management of the Tonle Sap Lake: An Integrated Modelling Approach. Water Resources Development, Vol.22, No.3, pp. 497-519

Lohse, K.A.; Newburn, D.A.; Opperman, J.J. \& Merenlender, A.M. (2008). Forecasting relative impacts of land use on anadromous fish habitat to guide conservation planning. Ecological Applications, Vol.18, No.2, pp. 467-482

Mihelič, R.; Čop, J.; Jakše, M.; Štampar, F.; Majer, D.; Tojnko S. \& Vršič S. (2010). Smernice za strokovno utemeljeno gnojenje = Guidelines for professionally justified fertilisation . Ministry of Agriculture, Forestry and Food of Republic of Slovenia, Ljubljana

Montana Department of Environmental Quality (2005). Flathead Basin Program, quality assurance project plane (QAPP). Land and Water Quality Consulting/PBS\&J, Montana

Moriasi, D.N.; Arnold, J.G.; Van Liew, M.W.; Bingner, R.L.; Harmel, R.D. \& Veith, T.L. (2007). Model evaluation guidelines for systematic quantification of accuracy in watershed simulations. Transactions of the ASABE, Vol.50, No.3, pp. 885-900

Nash, J. \& Sutcliffe, J. (1970). River flow forecasting through conceptual models: I. A discussion of principles. Journal of Hydrology, Vol.10, pp. 374-387

Neal, C. \& Heatwaite, A.L. (2005). Nutrient mobility within river basins: a European perspective. Journal of Hydrology, Vol.304, pp. 477-490

Neitsch, S.L.; Arnold, J.G.; Kiniry, J.R. \& Williams, J.R. (2005). Soil and water assessment tool theoretical documentation - Version 2005. Texas Agricultural Experiment Station, Blackland Research Center, Agricultural Research Service, Grassland, Soil and Water Research Laboratory, Texas, Temple

Pedosphere (2009). Soil Texture Triangle Hydraulic Properties Calculator, 21. July 2010, Available from http://www.pedosphere.com/

Petek, F. (2007). Spreminjanje rabe tal v severnih Goriških brdi. Geografski vestnik, Vol.79, No.1, pp. 9-23 
Ramos, M.C. \& Martinez-Casasnovas, J.A. (2006). Nutrient losses by runoff in vineyards of the Mediterranean Alt Penede`s region (NE Spain). Agriculture, Ecosystems and Environment, Vol.113, pp. 356-363

Randhir, T.O. \& Hawes, A.G. (2009). Watershed land use and aquatic ecosystem response: Ecohydrologic approach to conservation policy. Journal of Hydrology, Vol.364, pp. 182-199

Rusjan, S. (2008). Hidrološke kontrole sproščanja hranil v porečjih = Hydrological controls of nutrient mobilization in watersheds. Doctoral thesis. University of Ljubljana, Ljubljana

Saxton, K.E.; Rawls, W.J.; Romberger, J.S. \& Papendick, R.I. (1986). Estimating generalized soil-water characteristics from texture. Soil Science Society of America Journal, Vol.50, No.4, pp. 1031-1036

Schoumans, O.F.; Silgram, M.; Walvoort, D.J.; Groenendijk, P.; Bouraoui, F.; Andersen, H. E.; Lo Porto, A.; Reisser, H.; Le Gall, G.; Anthony, S.; Arheimer, B.; Johnsson, H.; Panagopoulos, Y.; Mimikou, M.; Zweynert, U.; Behrendt, H. \& Barr, A. (2009). Description of nine nutrient loss models: capabilities and suitability based on their characteristics. Journal of Environmental Monitoring, Vol.11, pp. 506-514

van Griensven, A.; Meixner, T.; Grunwald, S.; Bishop, T.; Di Luzio, M. \& Srinivasan, R. (2006). A global sensitivity analysis tool for the parameters of multi-variable catchment models. Journal of Hydrology, Vol.324, pp. 10-23

Volk, M.; Liersch, S. \& Schmidt, G. (2009). Towards the implementation of the European Water Framework Directive? Lessons learned from water quality simulations in an agricultural watershed. Land Use Policy, Vol.26, pp. 580-588

Wagner, W.; Gawel J.; Furumai, H.; Pereira De Souza, P.; Teixeira, D.; Rios, L.; Ohgaki, S.; Zehnder, A.J.B. \& Hemond, H.F. (2002). Sustainable watershed management: An international multi-watershed case study. Ambio, Vol.31, No.1, pp. 2-13

Wolfe, M.L. (2000). Hydrology. In: Agricultural nonpoint source pollution:: Watershed management and hydrology, W.F. Ritter \& A. Shirmohammadi, (Ed.), Lewis Publishers, Boca Raton 


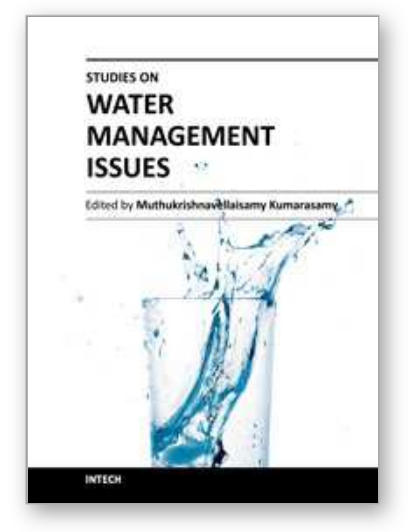

\author{
Studies on Water Management Issues \\ Edited by Dr. Muthukrishnavellaisamy Kumarasamy
}

ISBN 978-953-307-961-5

Hard cover, 274 pages

Publisher InTech

Published online 18, January, 2012

Published in print edition January, 2012

This book shares knowledge gained through water management related research. It describes a broad range of approaches and technologies, of which have been developed and used by researchers for managing water resource problems. This multidisciplinary book covers water management issues under surface water management, groundwater management, water quality management, and water resource planning management subtopics. The main objective of this book is to enable a better understanding of these perspectives relating to water management practices. This book is expected to be useful to researchers, policy-makers, and non-governmental organizations working on water related projects in countries worldwide.

\title{
How to reference
}

In order to correctly reference this scholarly work, feel free to copy and paste the following:

Matjaž Glavan and Marina Pintar (2012). Modelling of Surface Water Quality by Catchment Model SWAT, Studies on Water Management Issues, Dr. Muthukrishnavellaisamy Kumarasamy (Ed.), ISBN: 978-953-307961-5, InTech, Available from: http://www.intechopen.com/books/studies-on-water-managementissues/modelling-of-surface-water-quality-by-catchment-model-swat

\section{INTECH}

open science | open minds

\section{InTech Europe}

University Campus STeP Ri Slavka Krautzeka 83/A 51000 Rijeka, Croatia Phone: +385 (51) 770447

Fax: +385 (51) 686166 www.intechopen.com

\section{InTech China}

Unit 405, Office Block, Hotel Equatorial Shanghai No.65, Yan An Road (West), Shanghai, 200040, China 中国上海市延安西路65号上海国际贵都大饭店办公楼 405 单元 Phone: +86-21-62489820

Fax: $+86-21-62489821$ 
(C) 2012 The Author(s). Licensee IntechOpen. This is an open access article distributed under the terms of the Creative Commons Attribution 3.0 License, which permits unrestricted use, distribution, and reproduction in any medium, provided the original work is properly cited. 